\title{
Spectral characterization of periglacial surfaces and geomorphological units in the Arctic Lena Delta using field spectrometry and remote sensing
}

\author{
Mathias Ulrich ${ }^{\mathrm{a}, *}$, Guido Grosse ${ }^{\mathrm{b}}$, Sabine Chabrillat ${ }^{\mathrm{c}}$, Lutz Schirrmeister ${ }^{\mathrm{a}}$ \\ a Alfred Wegener Institute for Polar and Marine Research, Research Unit Potsdam, Telegrafenberg A45, 14473 Potsdam, Germany \\ b Geophysical Institute, University of Alaska, Fairbanks, AK 99775-7320, USA \\ c GeoForschungsZentrum Potsdam, Telegrafenberg A17, 14473 Potsdam, Germany
}

\section{A R T I C L E I N F O}

\section{Article history:}

Received 30 May 2008

Received in revised form 5 February 2009

Accepted 11 February 2009

\section{Keywords:}

Field spectrometry

Spectral properties

Land-cover classification

Periglacial surface features

Lena Delta

North Siberia

\begin{abstract}
A B S T R A C T
Important environmental parameters in arctic periglacial landscapes (i.e. permafrost temperature, activelayer depth, soil moisture, precipitation, vegetation cover) will very likely change in a warming climate. The thawing of permafrost, especially, might cause massive landscape changes due to thermokarst and an enhanced release of greenhouse gasses from the large amounts of carbon stored in frozen deposits, resulting in positive climate-warming feedback. For the identification, mapping, and quantification of such changes on various scales up to the entire circum-Arctic, remote sensing and spatial data analysis are essential tools. In this study an extensive field-work dataset including spectral surface properties, vegetation, soils, and geomorphology was acquired in the largest Arctic delta formed by a single river, the Siberian Lena River Delta. A portable field spectrometer (ASD FieldSpec Pro FRß) was used for spectral surveys of terrain surfaces, and optical satellite data (Landsat Enhanced Thematic Mapper (ETM+), CHRIS-Proba) were used for the characterization, manual mapping, and automatic classification of typical periglacial land-cover units in the Lena Delta. Qualitative data from soils, vegetation, soil moisture, and relief units were correlated with the field-spectral data and catalogued for a wide variety of surface types. The wide range of micro- and mesoscale variations of periglacial surface features in the delta results in distinctive spectral characteristics for different land-cover units. The three main delta terraces could also be spectrally separated and characterized. The present dataset provides a basis for further spectral data acquisitions in the Lena Delta and for comparisons with periglacial surfaces from other regions.
\end{abstract}

(c) 2009 Elsevier Inc. All rights reserved.

\section{Introduction and background}

Most climate simulations predict considerable climate warming, especially in the Arctic, over the next century (ACIA, 2005). Permafrost regions, which cover about $24 \%$ of the Northern Hemisphere land surface (Zhang et al., 1999), are considered highly sensitive to climate change (e.g. Nelson et al., 2002; Sazonova et al., 2004). In this context, the monitoring of arctic permafrost landscapes is an important challenge; we must understand the present in order to quantify future environmental changes and their impacts in the Arctic. Permafrost, clearly a climatically-controlled phenomenon, results in special frost-related structures, land-surface features, and processes summarized by the term "periglacial" (Everdingen, 2005). In the periglacial environment, permafrost degradation and aggradation are controlled by climate variations and local factors that influence soil temperature fluctuations. Disturbances of the sensitive near-surface

\footnotetext{
* Corresponding author. Tel.: +49 331 2882156; fax: +49 3312882137. E-mail address: Mathias.Ulrich@awi.de (M. Ulrich).
}

thermal-energy permafrost balance have a large impact on periglacial landscape formation and the tundra ecosystem. One of the most important local factors influencing permafrost distribution and thickness is the type of vegetation cover, which can act as an insulator buffering the interaction between surface and ground thermal regimes (Kade et al., 2006). The thawing of permafrost deposits that contain ground ice results in surface subsidence (thermokarst) and the formation of characteristic depressions in the landscape. Thermokarst formation results in the increase of greenhouse gas emissions to the atmosphere because warming releases old carbon pools from frozen deposits (Walter et al., 2006; Zimov et al., 2006); this process is probably a highly-significant climate influence during periods of warming like in the early Holocene (Walter et al., 2007). Regions of wet tundra in periglacial landscapes, found in many thermokarst basins and floodplains in Arctic lowlands, are also considered to be strong methane sources since Arctic permafrost soils often contain large amounts of organic carbon. The soils' syngenetically frozen plant remains and peat horizons form large and climate-sensitive carbon reservoirs in the Arctic (Goryachkin et al., 1999; Wagner et al., 2007).

Remote sensing provides the most prospective tools for monitoring changes in the remote and vast arctic periglacial environments. 
Approaches include mapping permafrost distribution and periglacial geomorphology (e.g. Boike \& Yoshikawa, 2003; Etzelmüller et al., 2001; Frohn et al., 2005; Grosse et al., 2005; Peddle \& Franklin, 1993; Zhang et al., 2004) and land-cover mapping and change detection (e.g. Olthof \& Fraser, 2007; Rees et al., 2003; Stow et al., 2004). In this study we present a detailed Landsat Enhanced Thematic Mapper (ETM+)based land-cover classification for a western Lena Delta study site. CHRIS-Proba data were used for soil mapping in a thermokarst depression.

The successful interpretation of remote-sensing data requires substantial field work to understand the small-scale variations that are common in periglacial environments. In addition to the characterization of vegetation, soils, and geomorphology, the acquisition of spectral surface properties is essential to capture environmental variability and related land-surface processes. For our study, a portable field spectrometer was used that allowed hyperspectral measurements of specific objects or surfaces in their natural environment in the visible (VIS, 400-700 nm), near-infrared (NIR, 700-1300 nm) and short-wave infrared (SWIR, 1300$2500 \mathrm{~nm}$ ) wavelength ranges. For the first time, we acquired a comprehensive dataset on spectral properties of periglacial tundra surfaces in the Lena Delta. Currently, there are only a few field spectrometer studies of arctic periglacial environments, mostly focusing on reflectance properties from different tundra types (Hope et al., 1993; Riedel et al., 2005; Stow et al., 1993; Vierling et al., 1997). The reflectance-based normalized difference vegetation indices (NDVIs) calculated in these studies were generally dependent on surface conditions and on the composition of tundra vegetation communities. The broad-band albedo of arctic and subarctic surfaces as a function of surface and sky conditions was measured by Petzold and Rencz (1975) and Hope et al. (1991). A high-resolution field spectrometer was used by Hinkler et al. (2003) for differentiating surface types by albedo measurements during the snowmelt season at Svalbard. Detailed description of the spectral features of subarctic lichens determined from hyperspectral reflectance measurements was presented by Rees et al. (2004). Near-surface-moisture conditions were monitored in northern peatlands by Harris et al. (2005), using reflectance spectra of Sphagnum moss. More detailed studies of diverse vegetation types and surface conditions exist for lower-latitude regions (e.g. Chabrillat et al., 2002; Okin et al., 2001; Pinker \& Karnieli, 1995; Schmidt \& Skidmore, 2003; van Til et al., 2004), often with focus on soil moisture (e.g. Weidong et al., 2002), leaf biochemistry (e.g. Elvidge, 1990; Jago et al., 1999), or vegetation water content (e.g. Ceccato et al., 2001; Pu et al., 2003).

The spectral characteristics of objects and surfaces depend on their chemical and biophysical properties, and on viewing and illumination geometry (Curtiss \& Goetz, 1994; Milton et al., 1995; Milton, 1987). In the natural tundra environment of the Lena Delta three major spectral groups can be distinguished: vegetation, bare soil, and surface water (Fig. 1). However, the spectral surface signatures are usually complex mixed signals influenced by type and state of vegetation, soil surface features, and moisture content in soils and vegetation. Differences in reflectance spectra and especially in specific absorption features in the VIS to SWIR region (400$2500 \mathrm{~nm}$ ) can be used to differentiate a wide variety of surfaces. The spectral reflectance of vegetation is influenced by leaf pigments (mainly chlorophyll), cellulose in dry vegetation, cell structure, water content, and canopy structure, and depends on the phenological stage in the growing season. There are two main spectral signatures of vegetation. Spectra of green, photosynthetically active vegetation are characterized by low reflectance in the VIS, strong chlorophyll absorption at $680 \mathrm{~nm}$, and high reflectance as well as strong water-absorption bands in the NIR and SWIR. These waterabsorption features, mainly centred at about $970 \mathrm{~nm}, 1200 \mathrm{~nm}$, $1450 \mathrm{~nm}$, and $1930 \mathrm{~nm}$, are correlated with and can be used to assess leaf water content (e.g. Clevers et al., 2008; Pu et al., 2003; Seelig et al., 2008). Most characteristic is the point of maximum slope in the reflectance spectra of green vegetation around $690-740 \mathrm{~nm}$. This point, termed the "red edge" (e.g. Curran et al., 1990), marks the boundary between chlorophyll absorption and the high reflectance in the NIR by green plants. There is a strong correlation between the appearance of the red edge and the vitality of vegetation (Curran et al., 1990; Rock et al., 1988). The spectral reflectance of dry, nonphotosynthetically-active vegetation is influenced by the absorption of cellulose and lignin in the SWIR and the lack of absorption by chlorophyll and water.

The spectral signature of bare soil (Fig. 1) typically increases with wavelength in the VIS and stays relatively constant in the NIR and SWIR. The spectral reflectance and absorption features are affected by soil moisture, texture, mineral content, and organic matter. A coarse-grained, wet soil has lower reflectance than a fine-grained, dry soil (Clark, 1999; van der Meer, 2004). Generally, the reflectance decreases when soil moisture increases (Weidong et al., 2002). Estimating soil moisture using distinct waterabsorption features is rather difficult if the soil is covered by vegetation. Usually, measurements of the broad absorption bands centred at $1450 \mathrm{~nm}$ and $1930 \mathrm{~nm}$ are only feasible under laboratory conditions, since these bands are affected by atmospheric water vapour.

The reflectance of water is low in all spectral ranges. The reflectance increases in the visible spectral range if the water contains suspended material.

The main goal of this study is the general characterization and classification of periglacial surfaces and geomorphological units in the Lena Delta by their spectral properties. Subordinate goals are: (i) the creation of a field spectra database for periglacial and tundra surfaces in the central and western delta to aid current and future multi- and hyperspectral land-cover mapping in the Lena Delta; (ii) the development of a detailed land-cover classification based on Landsat ETM+; and (iii) the mapping of pedological units in the western Lena Delta using CHRIS-Proba data. The purpose of all these goals is to generate a remotely-sensed base dataset for detecting and quantifying long-term changes in the climate-sensitive permafrost environment of the Lena Delta.

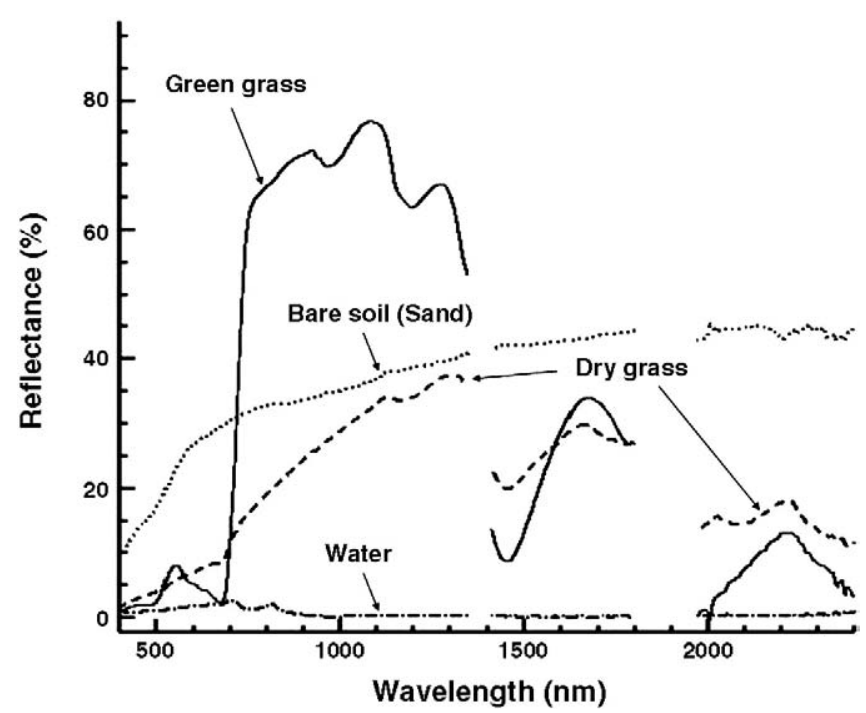

Fig. 1. Spectral signatures of green and dry grass, bare soil, and water in tundra landscapes (August 2005). The measurements were performed using an ASD FieldSpec Pro FR®. Noise by atmospheric water absorption around $1350-1415 \mathrm{~nm}$ and 1800 $1970 \mathrm{~nm}$ is masked. Note the distinct absorption features for green vegetation: Chlorophyll at $680 \mathrm{~nm}$, and water at $970 \mathrm{~nm}$ and $1200 \mathrm{~nm}$. 


\section{Study area}

The Lena Delta is located at the Laptev Sea coast, NE Siberia (Fig. 2). The Lena Delta is the largest Arctic delta formed by a single river, and covers about $29,000 \mathrm{~km}^{2}$. The delta is located in the zone of continuous permafrost with permafrost depths of 500-600 m (Grigoriev et al., 1996), and it is dominated by fluvial-deltaic and periglacial processes. The typical maximum active-layer depths range from 30 to $90 \mathrm{~cm}$. Taliks (i.e. "multi-annually unfrozen ground occurring in a permafrost area", Everdingen, 2005) occur below large water bodies, namely thermokarst lakes and delta channels (Grigoriev, 1993). The climate is true-arctic, with a mean annual air temperature of about $-14{ }^{\circ} \mathrm{C}$ and a mean annual precipitation around $250 \mathrm{~mm}$ (WWIS, 2006). The delta consists of more than 1500 islands of various sizes. One of the largest, with an area of about $7000 \mathrm{~km}^{2}$, is Arga-Muora-Sise Island in the northwestern part of the delta. Most of the Lena Delta is geomorphologically active, and consists of wetlands with heterogeneous micro-relief. Thaw depressions with thermokarst lakes, ice-wedge polygons, and pingos are common. According to the Circumpolar Arctic Vegetation Map (CAVM), the delta exists in bioclimatic subzones $\mathrm{C}$ and $\mathrm{D}$, and is dominated by sedge, grass, moss, and dwarf shrub wetlands (CAVM Team, 2003). Large parts of the polygonal tundra landscape in the delta are occupied by typical arctic, hydromorphic soils with thick peat horizons.

The Lena Delta is subdivided into three main geomorphological terraces (Fig. 2) based on differences in cryolithology, hydrology, and geomorphology (Are \& Reimnitz, 2000; Grigoriev, 1993). The first terrace (1-12 masl) includes Holocene and recent floodplains, and represents the modern "active" delta. The slightly elevated Holocene floodplains mainly consist of typical ice-wedge polygonal tundra with strong micro-relief and a highly variable hydrological regime (Boike et al., 2008). The second terrace (11-30 masl) is characterized by sandy deposits of late Pleistocene to early Holocene fluvial genesis. On this terrace, strongly NNE-SSWoriented thaw depressions with thermokarst lakes are abundant (Fig. 3). The specific landscape characteristics of this terrace, also referred to as the Arga Complex, differ substantially from the other delta units. Its geological genesis is still under investigation and is debated (Are \& Reimnitz, 2000; Schwamborn et al., 2000, 2002). The third Lena Delta terrace (30-60 masl) is formed by erosional remnants of a late Pleistocene accumulation plain of ice-rich and organic-rich deposits (Ice Complex or Yedoma) underlain by sandy sequences. The deposits of this unit often contain paleo-soils and thick peat horizons (Schirrmeister et al., 2003; Wetterich et al.,

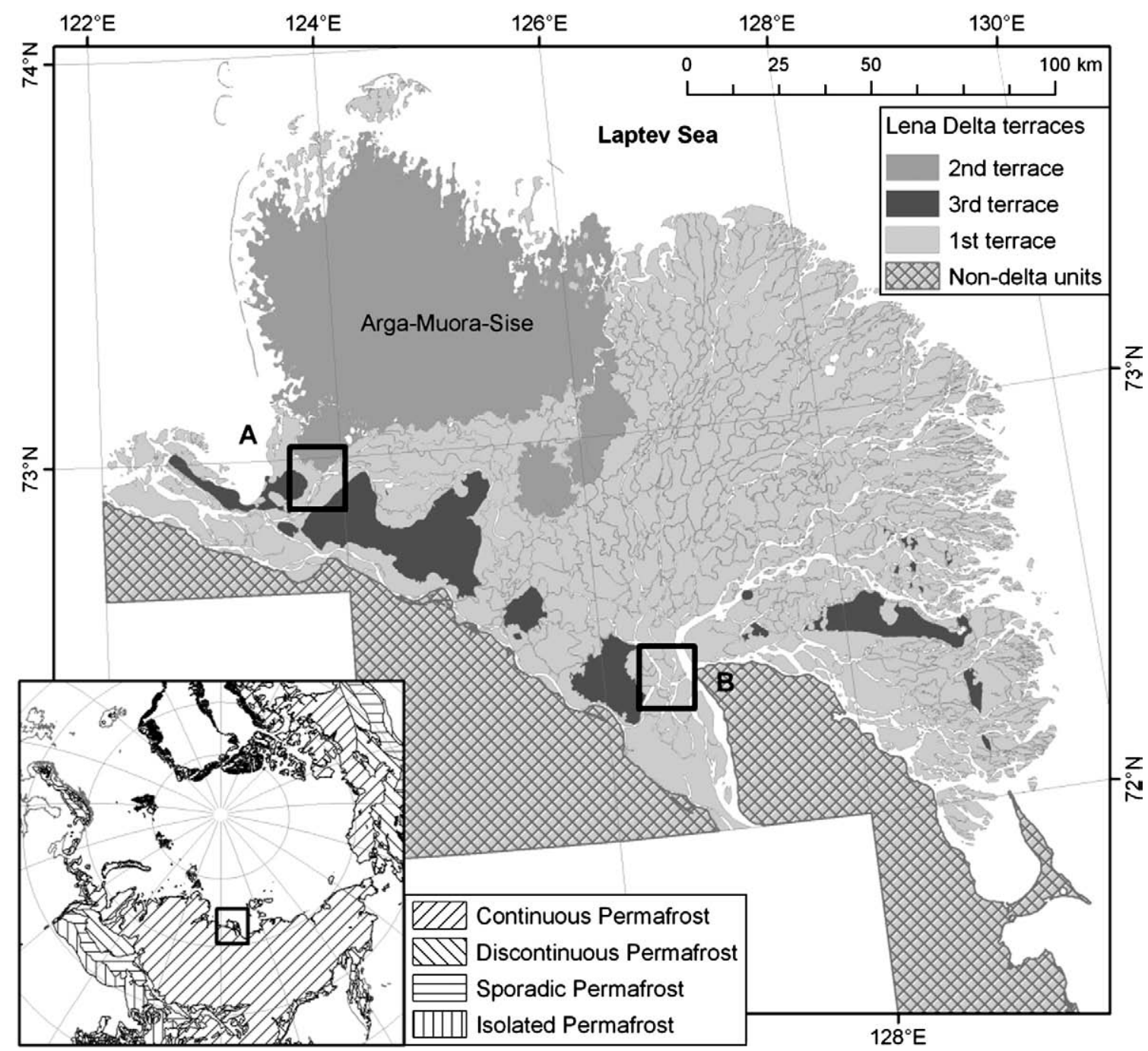

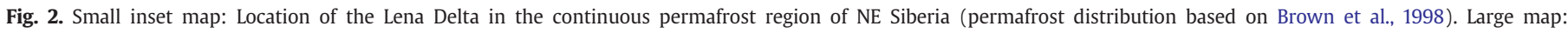

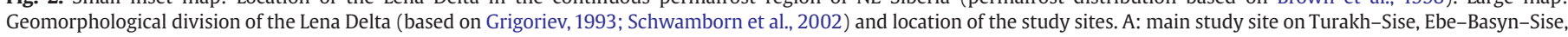
and Khardang-Sise islands; B: study sites on Samoylov and Kurungnakh-Sise islands. 

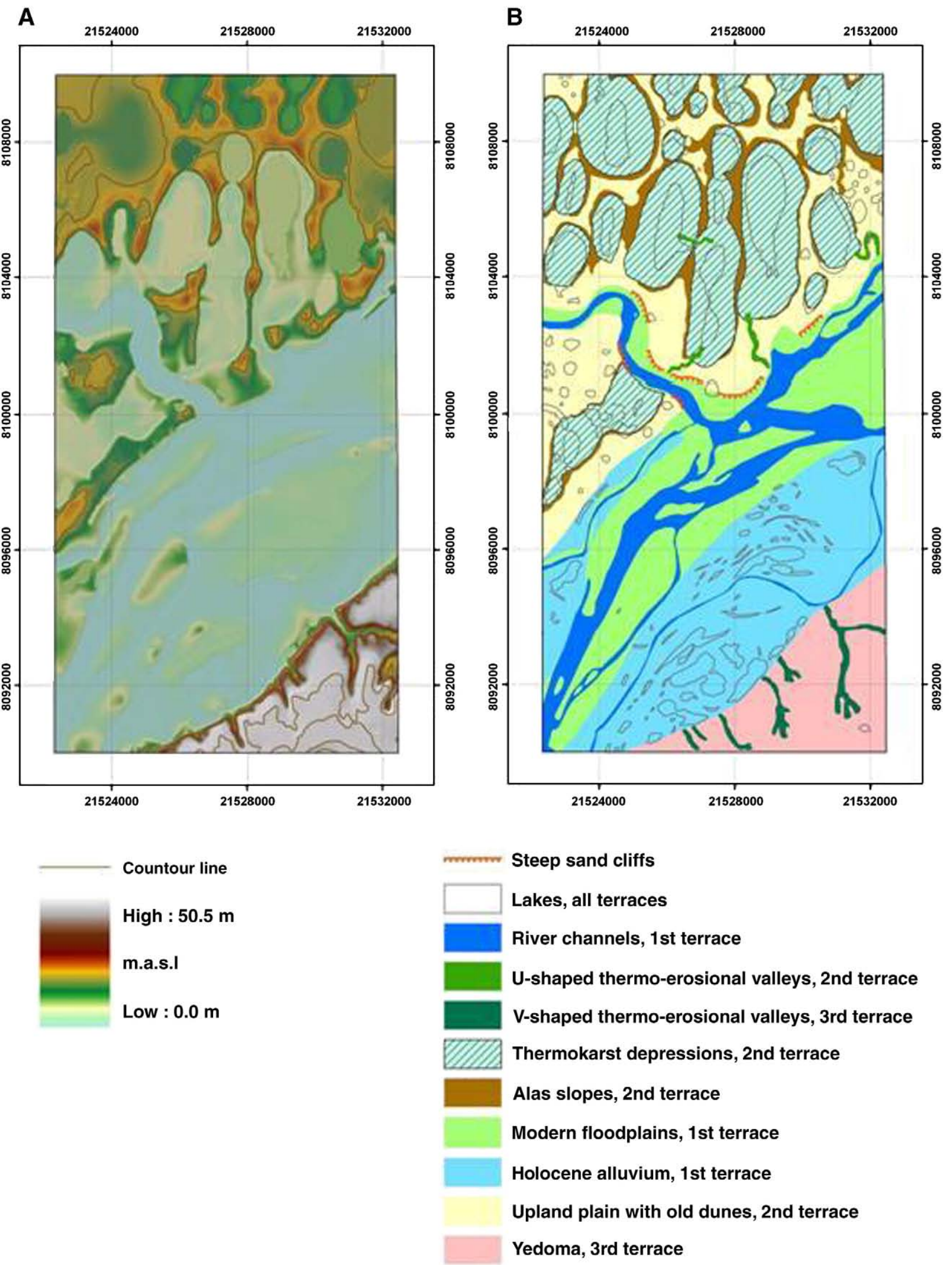

Fig. 3. A - digital elevation model (DEM) for the Turakh study site. B - DEM- and Corona-derived geomorphological map for the Turakh study site.

2008). For our detailed study we focused on Turakh-Sise Island, Ebe-Basyn-Sise Island, and Khardang-Sise Island (Fig. 2, site A) in the western delta, hereafter named the Turakh study site, although some measurements were additionally carried out on Samoylov and Kurungnakh-Sise islands in the central Lena Delta (Fig. 2, site B). The study areas cover all three geomorphological terraces and a 
Table 1

Instrument details for the ASD FieldSpec Pro Fr® field spectrometer.

\begin{tabular}{|c|c|}
\hline Spectral range & $350-2500 \mathrm{~nm}$ \\
\hline \multirow[t]{3}{*}{ Detectors } & VNIR: photo-diode array (350-1000 nm) \\
\hline & SWIR 1: scanning spectrometer (1000-1770 nm) \\
\hline & SWIR 2: scanning spectrometer (1770-2500 nm) \\
\hline $\begin{array}{l}\text { Wavelength } \\
\text { accuracy }\end{array}$ & $\pm 1 \mathrm{~nm}$ \\
\hline $\begin{array}{l}\text { Ground } \\
\text { resolution }\end{array}$ & $\begin{array}{l}\text { Using bare optics ( } 24^{\circ} \text { field of view) and } 1 \mathrm{~m} \text { altitude resulting } \\
\text { in a circle of about } 0.2 \mathrm{~m} \text { radius }\end{array}$ \\
\hline \multirow{2}{*}{$\begin{array}{l}\text { Spectral } \\
\text { resolution }\end{array}$} & $3 \mathrm{~nm}$ for $350-1000 \mathrm{~nm}$ \\
\hline & $10-12 \mathrm{~nm}$ for $1000-2500 \mathrm{~nm}$ \\
\hline \multirow[t]{3}{*}{ Data channels } & 512 for $350-1000 \mathrm{~nm}$ \\
\hline & 1060 for $1000-2500 \mathrm{~nm}$ \\
\hline & Interpolated data points: every $1 \mathrm{~nm}$ (2151 total) \\
\hline Field of view & $\begin{array}{l}\text { Variable (dependent on chosen foreoptic): } 24^{\circ} \text { (bare optic), } \\
1^{\circ} \text { or } 8^{\circ} \text { (foreoptic lenses) }\end{array}$ \\
\hline Data acquisition & 1 scan every $100 \mathrm{~ms}(0.1 \mathrm{~s})$ \\
\hline
\end{tabular}

wide spectrum of tundra wetlands, deltaic features, and periglacial surface structures typical of the Arctic Lena Delta.

\section{Data and methods}

\subsection{Field-spectral measurements}

Extensive field data were collected in the central and western Lena Delta, NE Siberia, during the joint Russian-German expedition "Lena Delta 2005" in summer 2005 (Ulrich \& Grosse, 2007). Field work included geomorphological mapping, description of surface properties including vegetation characteristics, pedological surveys, and collection of land-surface reflectance spectra. The field-reflectance spectra were measured in the spectral range 350-2500 $\mathrm{nm}$ with an ASD (Analytical Spectral Devices Inc.) FieldSpec Pro FR ${ }^{\circledR}$ (see Table 1 for instrument details). The measurements were conducted on predominantly clear-sky days around solar noon during 12-31 August 2005. Data were acquired following regular reflectance calibration with a Spectralon ${ }^{\circledR}$ white panel (Labsphere, Inc.). A scanning time of $5 \mathrm{~s}$ was used to acquire one spectrum. Since the scanning time of the instrument is $100 \mathrm{~ms}$ (Table 1 ), each acquired spectrum represents an average of 50 individual measurements. Applying this averaging procedure increases the signal-to-noise ratio of the resulting reflectance measurement. For most measurements a bare foreoptic was used with an instantaneous $24^{\circ}$ field of view. The footprint for nadir measurements at $1 \mathrm{~m}$ height covered a circle with $0.2 \mathrm{~m}$ radius. Additionally, when the operator was moving forward during the 5-slong recording process (e.g. profile measurements), the resulting spectral signal is integrated over a larger area that is more representative of the heterogeneous periglacial tundra surface typical of the investigation area. During the field work we carried out both point and profile measurements on specific surface types. Point measurements included 2 spectra each, averaging 50 individual measurements at sites selected for their distinctive surface characteristics. Profile measurements represent transects of continuous spectrometer samples taken at walking speed across a variety of surface types. The length of these transects varied between 40 and $150 \mathrm{~m}$, and both start-point coordinates were determined. Altogether, spectral measurements were accomplished at 19 locations with different surface characteristics. These include spectra from two sites on Turakh-Sise Island and eleven sites on Ebe-Basyn-Sise Island, both in the main study site in the western Lena Delta (Fig. 2, site A). Additionally, four sites on Samoylov Island and two sites on Kurungnakh-Sise Island in the central Lena Delta were measured (Fig. 2, site B). For each location and measurement, weather conditions, soil properties, active-layer depths, geomorphological situation, and vegetation properties were recorded in combination with the field spectra for detailed characterization of different surfaces types, e.g. polygonal structures, thermokarst units, floodplain levels, and sand banks (Ulrich \& Grosse, 2007).

Frequent unfavourable weather conditions accompanied by high cloud cover limited the acquisition of field-spectral data in the Laptev Sea region. Due to these conditions, only a few days were available during the field campaign for successfully measuring reflectance spectra. We additionally tried to reduce errors by continuously referencing the field spectrometer with the Spectralon ${ }^{\circledR}$ white reference panel in between the target measurements.

\subsection{Field spectra processing}

The resulting dataset of 519 field spectra was processed with ENVI $^{\mathrm{TM}}$ and catalogued into separate spectral libraries for point measurements and profile measurements according to the investigated field sites. Further, detector splice correction was carried out and transformation to absolute reflectance measurements was based on the Spectralon ${ }^{\circledR}$ surface radiometry. The spectral regions associated with strong atmospheric water absorption around $1400 \mathrm{~nm}$, $1900 \mathrm{~nm}$, and above $2400 \mathrm{~nm}$ were masked out. Spectra acquired during profile measurements were averaged into one spectrum which represents the specific surface type.

Beyond extensive visual analyses of the spectral reflectance features, more detailed differentiation of the field spectra was achieved by applying the continuum-removal technique (Clark \& Roush, 1984) for certain indicative wavelength ranges. Continuum removal is a normalization technique that allows the comparison of individual absorption features from a common baseline. The method is widely used for geological applications (e.g. van der Meer, 2004) as well as for the discrimination of vegetation types (Schmidt \& Skidmore, 2003). The continuum is a convex hull fitted over the top of a spectrum. The line connects all local maxima of the spectrum. The first and the last values of the represented continuum are normalized to a relative value of 1 . The location and the depth of individual absorption features are emphasized as the quotient of the continuum. We used the continuum-removal technique for the chlorophyll absorption band at $680 \mathrm{~nm}$ and the water-absorption band centred at $\sim 1160 \mathrm{~nm}$, determined from the $1120-1240 \mathrm{~nm}$ spectral range. We were able to compare and evaluate the vitality of vegetation cover due to the chlorophyll absorption depth and to differentiate the leaf water content as well as the surface moisture due to the water-absorption depth. Finally, after applying intensive visual analyses and the continuum-removal technique, we grouped the profile spectra based on specific periglacial surface types (e.g. polygonal tundra, thermokarst depressions units, and floodplain levels) and the Lena Delta geomorphological terraces.

\subsection{Satellite data processing}

The Turakh study site ( site A in Fig. 2) was covered by a subset of a Landsat ETM + satellite image from 26 July 2001. The Landsat level $1 G$ data (standard radiometric and geometric corrections) was atmospherically corrected by Schneider et al. (2009) according to Chavez (1996). A subset of the Turakh study site with bands 1 to 5 and 7 was created for the classification. The spectral bands cover the VIS, NIR, and SWIR region (400-2500 nm) with $30 \mathrm{~m}$ ground resolution. Conducting image classifications unsupervised and supervised techniques were used in the ENVI ${ }^{\mathrm{TM}}$ image processing software. At first, an unsupervised classification applying an ISODATA cluster algorithm (Tou \& Gonzalez, 1974) was accomplished for preliminary indication of the general class composition. A supervised classification (maximum-likelihood algorithm) based on training areas derived from our detailed field knowledge resulted in 15 land-cover classes. The ndimensional visualizer tool in the ENVI ${ }^{\mathrm{TM}}$ software was applied to separate the class endmembers in the six-dimensional space of the Landsat dataset. Finally, the spatial distribution of the classification 
results was analysed and the class distribution for the main geomorphological units in the main study area was characterized using Regions of Interest (ROIs) derived from Geographic Information System (GIS) geomorphological mapping (Fig. 3).

Furthermore, radiance top-of-atmosphere CHRIS-Proba satellite data (29 June 2005, $17 \mathrm{~m}$ ground resolution at nadir) were used to create a soil map of a large thermokarst depression and adjacent slopes on Turakh-Sise Island. The European Space Agency (ESA) CHRIS-Proba mission provides hyperspectral satellite data in several spectral modes. We used the CHRIS land-channel mode 3 data with 18 spectral bands in the wavelengths between $438-1035 \mathrm{~nm}$ with 6-33 nm band width. The visual mapping was based on a RedGreen-Blue (RGB) colour composite measured on 17/11/04 (Red NIR band 17-910 nm, Green NIR band 11-712 nm, Blue NIR band 4$551 \mathrm{~nm})$.

\subsection{Data for geomorphology, soils, and surface properties}

Altogether, characteristics and surface properties were collected at 73 locations in the Lena Delta study region (Ulrich \& Grosse, 2007). Described parameters included relief properties (i.e. exposition, curvature, estimated slope degree) and surface soil properties. Active-layer depths were measured using a steel rod. Vegetation characteristics were recorded for the measured spectrometer footprint ( $0.4 \mathrm{~m}$ diameter) by identifying the dominating species or genus, visually estimating its overall percentage cover, and describing plant phenology, vitality (fresh, drying, or dead), and canopy height. In addition, eight soil profiles were pedologically analysed, five from a catena within a thermokarst depression. Soils were classified according to American (Soil Survey Staff, 2003) and German (AG Boden, 1994) soil taxonomies describing horizon succession, texture, structure, colour, humus content, root density, and reduction-oxidation (redox) potential. Soil samples were additionally analysed for grainsize composition and organic-carbon content using a laser particle analyser (Beckmann Coulter LS 200) and a CNS-Analyser (Elementar Vario EL III), respectively (Table 2). The general relief of the Turakh study area was analysed with a raster digital elevation model (DEM) created with the TOPOGRID tool of ArcGISTM (ESRI) (Fig. 3A). The DEM is based on manually-digitized elevation data (contours, elevation points, streams, lakes) from a topographical map $(1: 100,000)$. This topographic map series was originally derived from finer-scale maps which are, in turn, based on aerial images, at a scale of $1: 40,000$ or better. The local relief has an elevation range of $0-50 \mathrm{~m}$, providing enough topography to derive slope profiles, basin and upland morphology, and major drainage networks. The contour interval is $10 \mathrm{~m}$. Generally, steep bluffs along river channels are poorly captured. Though not very useful for hydrological research, the DEMs from such topomaps are of sufficient quality for geomorphological mapping, as already described in Grosse et al. (2006). Comparison with a highresolution Corona satellite image (22 June 1964, panchromatic, $2.5 \mathrm{~m}$ ) also indicates reasonably good map qualities. The elevation grid was generated in $30 \mathrm{~m}$ cells to match the Landsat pixel size. For geomorphological mapping we used DEM field-survey knowledge, high-resolution Corona data, and the Landsat ETM+ image (26 July 2001) (Fig. 3B).

\section{Results}

\subsection{Spectral properties of periglacial surfaces from field spectrometry}

The individual measurement sites are characterized by a range of typical Arctic tundra vegetation communities: sedges, grasses, mosses, lichen, herbs, and low shrubs (Table 3). In most cases canopy height was less than $30-50 \mathrm{~cm}$. Vegetation coverage ranged from $0-$ $100 \%$, strongly depending on geomorphological position and drainage conditions. Measured active-layer depths at the sites ranged from 25$100 \mathrm{~cm}$, depending on vegetation type, local meso- and micro-relief, drainage conditions, and soil lithology.

Table 2

Summary of analysed soil sample parameters.

\begin{tabular}{|c|c|c|c|c|c|c|c|c|c|}
\hline Location & Soil-tax name & Horizon (soil-tax) & Depth $(\mathrm{mbs})^{\mathrm{a}}$ & Lithology & $\mathrm{pH}$ & TOC $(\%)$ & $\mathrm{TN}(\%)$ & $\mathrm{C} / \mathrm{N}$ & Grain size $(\mu \mathrm{m})$ \\
\hline \multirow[t]{10}{*}{ Samoylov Island } & \multirow[t]{4}{*}{ Glacic Psammoturbel } & Ah & $0.1-0.12$ & Silt, sand & 5.77 & 1.22 & 0.10 & 11.20 & 220.3 \\
\hline & & B1w & $0.12-0.15$ & Silt, sand & 5.85 & 0.94 & 0.10 & 8.70 & 215.2 \\
\hline & & B2wjj & $0.15-0.22$ & Silt, sand & 5.94 & 0.86 & 0.10 & 8.48 & 207.5 \\
\hline & & B3wjj & $0.22-0.28$ & Silt, sand & 6.31 & 1.90 & 0.18 & 10.23 & 183.2 \\
\hline & \multirow[t]{6}{*}{ Psammentic Aquorthel } & $\mathrm{Ah}$ & $0-0.03$ & Fine-sand & 6.9 & 0.53 & 0.05 & 10.43 & 211.6 \\
\hline & & Oi1 & $0.03-0.06$ & Silt, sand & 6.99 & 1.30 & 0.09 & 13.63 & 204.3 \\
\hline & & Oi2 & $0.06-0.12$ & Peat & 7.11 & 1.50 & 0.09 & 16.20 & 376.8 \\
\hline & & $\mathrm{ABg}$ & $0.12-0.17$ & Silt, sand & 6.80 & 1.47 & 0.08 & 16.67 & 287.1 \\
\hline & & $\mathrm{Bg} 1$ & $0.17-0.22$ & Middle sand & 6.46 & 0.56 & 0.07 & 7.58 & 221.9 \\
\hline & & Bg2 & $0.22-0.45$ & Middle sand & 6.02 & 0.57 & 0.06 & 9.34 & 221.5 \\
\hline \multirow[t]{5}{*}{ Ebe-Basyn-Sise Island } & \multirow[t]{5}{*}{ Typic Psammoturbel } & $\mathrm{Ah}$ & $0-0.04$ & Fine-sand & 4.65 & 2.14 & 0.20 & 10.47 & 198.9 \\
\hline & & $\mathrm{Bjj}$ & $0-04-0.1$ & Middle sand & 4.68 & 0.22 & 0.04 & 5.46 & 249.3 \\
\hline & & $\mathrm{Ah} 2 \mathrm{jj}$ & $0.1-0.18$ & Fine-sand & 4.63 & 0.39 & 0.08 & 4.91 & 211.1 \\
\hline & & Bw1 & $0.18-0.4$ & Middle sand & 4.81 & 0.14 & 0.02 & 5.0 & 269.1 \\
\hline & & Bw2 & $0.4-0.65$ & Middle sand & 4.72 & 0.06 & 0.02 & 3.42 & 276.9 \\
\hline \multirow{17}{*}{ Turakh-Sise Island (thermokarst depression) } & \multirow{4}{*}{ Typic Psammoturbel } & Ah & $0-0.03$ & Fine-sand & 4.87 & 1.04 & 0.12 & 8.18 & 203.8 \\
\hline & & Abjj & $0.03-0.36$ & Middle sand & 4.75 & 0.27 & 0.04 & 6.9 & 253.3 \\
\hline & & $\mathrm{Bjj}$ & $0.36-0.46$ & Middle sand & 4.71 & 0.30 & 0.05 & 6.03 & 252.2 \\
\hline & & Bw & $0.46-0.75$ & Middle sand & 4.73 & 0.12 & 0.03 & 3.78 & 272.9 \\
\hline & \multirow[t]{5}{*}{ Typic Psammoturbel } & Ah1 & $0-0.05$ & Fine-sand & 4.57 & 2.61 & 0.2 & 13.09 & 169 \\
\hline & & Bjj & $0.05-0.13$ & Middle sand & 4.95 & 0.21 & 0.03 & 6.41 & 284.5 \\
\hline & & Ah2 & $0.13-0.2$ & Middle sand & 4.88 & 0.64 & 0.07 & 8.46 & 183.7 \\
\hline & & Bw1 & $0.2-0.4$ & Middle sand & 4.71 & 0.09 & 0.01 & 5.11 & 251.6 \\
\hline & & Bw2 & $0.4-0.8$ & Middle sand & 4.72 & 0.06 & 0.01 & 3.94 & 291.4 \\
\hline & \multirow[t]{3}{*}{ Psammentic Aquorthel } & $\mathrm{Bg} 1$ & $0.03-0.12$ & Middle sand & 4.34 & 1.86 & 0.18 & 9.86 & 147.8 \\
\hline & & Bg1 & $0.12-0.18$ & Middle sand & 4.31 & 1.36 & 0.11 & 12.09 & 203.5 \\
\hline & & Bg2 & $0.18-0.7$ & Middle sand & 4.41 & 0.15 & 0.03 & 4.22 & 301.8 \\
\hline & Typic Aquorthel & $\mathrm{Bg} 2$ & $0.12-0.2$ & Fine-sand & 4.28 & 4.48 & 0.35 & 12.52 & 187 \\
\hline & \multirow[t]{4}{*}{ Typic Fibristil } & Oe & $0.1-0.3$ & Peat & 4.06 & 4.33 & 0.27 & 15.71 & 127.9 \\
\hline & & Oi2 & $0-0.1$ & Peat & 4.48 & 9.83 & 0.55 & 17.74 & 157.3 \\
\hline & & $\mathrm{L}$ & $0.3-0.5$ & Peat, silt & 3.98 & 2.56 & 0.18 & 13.61 & 117.9 \\
\hline & & C & $0.5-0.6$ & Middle sand & 4.18 & 0.11 & 0.02 & 4.52 & 267.5 \\
\hline
\end{tabular}

a mbs - meters below surface. 
Table 3

Field spectra and related surface characteristics for each field spectra class (Fig. 4) as well as comparable land-cover classes derived from Landsat ETM+ classification.

\begin{tabular}{|c|c|c|c|}
\hline Class & $\begin{array}{l}\text { Delta } \\
\text { terrace }\end{array}$ & Field-spectral characteristics & Related surface characteristics \\
\hline I & 3rd & $\begin{array}{l}\text { MaRe: } 38 \% \text { at } 1130 \mathrm{~nm} \text {; VIS: green reflectance shows local } \\
\text { maximum; ChloAb: clear but not deep; RE: distinct, bend and } \\
\text { decrease at } 740 \mathrm{~nm} \text {; NIR: increasing curve; SWIR: intimated } \\
\text { cellulose absorption; WaAb: clear but slightly }\end{array}$ & $\begin{array}{l}\text { Relatively dry and flat 3rd terrace surface, without polygonal } \\
\text { structure or irregular cracks, nearly homogeneous vegetation, } \\
\text { drier sites with Salix sp., mosses and lichens, moister sites } \\
\text { with green grasses and sedges on moos cushion, closed } \\
\text { vegetation cover, active-layer depth average } 40 \mathrm{~cm}\end{array}$ \\
\hline II & $3 r d$ & $\begin{array}{l}\text { MaRe: } 56 \% \text { at } 1150 \text {; VIS: local maximum in green reflectance } \\
\text { region, absorption in red pigment region; ChloAb: deep; RE: } \\
\text { high, bend and decrease at } 755 \mathrm{~nm} \text {; NIR: decreasing curve } \\
\text { down to } 920 \mathrm{~nm} \text {; SWIR: high, peaked bell-shaped curve; } \\
\text { WaAb: very deep }\end{array}$ & $\begin{array}{l}\text { Thaw depression, dry to moist surface after drainage of a } \\
\text { thermokarst lake ca. } 1985+/-5 \text { years, homogeneously tall } \\
\text { grasses (growth height }>50 \mathrm{~cm} \text { ), with many Salix sp. on } \\
\text { numerous thermokarst hills, closed vegetation cover }\end{array}$ \\
\hline III & 2nd & $\begin{array}{l}\text { MaRe: } 31 \% \text { at } 1140 \mathrm{~nm} \text {; VIS: low increase to red reflectance, } \\
\text { decrease in green reflectance; ChloAb: slightly; RE: short and } \\
\text { not steep, low shift to shorter wavelength; NIR: subhorizontal } \\
\text { to low, increasing curves; SWIR: intimated cellulose } \\
\text { absorption features; WaAb: clear but slight }\end{array}$ & $\begin{array}{l}\text { Low-centre polygonal tundra on the } 2 \text { nd terrace, poorly } \\
\text { drained centres with immersed sedges and Sphagnum sp., } \\
\text { elevated dryer rims with closed vegetation cover of dry } \\
\text { mosses, lichens, herbs, and dwarf shrubs, active-layer depth } \\
\text { average } 45 \mathrm{~cm} \text {, somewhat deeper in elevated rims }\end{array}$ \\
\hline V & 2nd & $\begin{array}{l}\text { MaRe: } 30 \% \text { at } 1280 \mathrm{~nm} \text {; VIS: flat curve with low increase; } \\
\text { ChloAb: indistinct; RE: very short with bend at } 730 \mathrm{~nm} \text {; NIR: } \\
\text { increasing curve; SWIR: distinct cellulose absorption; WaAb: } \\
\text { none at } 930-1030 \mathrm{~nm} \text {, slightly at } 1120-1240 \mathrm{~nm}\end{array}$ & $\begin{array}{l}\text { Thaw depression slopes, sandy, dry hummocky surfaces, } \\
\text { homogeneous distribution of dry mosses, crust lichens and } \\
\text { herbs, closed vegetation cover, growth height: } 2-10 \mathrm{~cm} \text {, } \\
\text { active-layer depth average } 80 \mathrm{~cm}\end{array}$ \\
\hline VI & 2nd & $\begin{array}{l}\text { MaRe: } 20-23 \% \text { at } 1120 \mathrm{~nm} \text {; VIS: flat curves with little } \\
\text { increase; one with intimated higher green reflectance at } \\
550 \mathrm{~nm} \text {; ChloAb: slightly; RE: short, bend at } 720-730 \mathrm{~nm} \text {; } \\
\text { NIR: low increasing curves up to } 1300 \mathrm{~nm} \text {; SWIR: intimated } \\
\text { cellulose absorption features; WaAb: indistinct at } 930- \\
1030 \mathrm{~nm} \text {, slight at } 1120-1240 \mathrm{~nm}\end{array}$ & $\begin{array}{l}\text { Thaw depressions, moist to very moist areas with indistinct to } \\
\text { distinct polygonal structures, vegetation is dominated by } \\
\text { sedges, mosses, and Salix sp., poorly drained sites dominated } \\
\text { by sedges and Sphagnum sp., drier sites dominated by Salix } \\
\text { sp., almost closed vegetation cover partly opened by stagnant } \\
\text { water, growth height: on average } 30 \mathrm{~cm} \text {, active-layer depth } \\
\text { average } 30-40 \mathrm{~cm}\end{array}$ \\
\hline
\end{tabular}

Comparable land-cover classes based on Landsat classification maximum; ChloAb: clear but not deep; RE: distinct, bend and structure or irregular cracks, nearly homogeneous vegetation, Complex) decrease at $740 \mathrm{~nm}$; NIR: increasing curve; SWIR: intimated drier sites with Salix sp., mosses and lichens, moister sites with green grasses and sedges on moos cushion, closed tepth average $40 \mathrm{~cm}$ thermokarst lake ca. $1985+/-5$ years, homogeneously tal grasses (growth height $>50 \mathrm{~cm}$ ), with many Salix sp. on high, bend and decrease at $755 \mathrm{~nm}$; NIR: decreasing curve $\quad$ numerous thermokarst hills, closed vegetation cover WaAb: very deep decrease in green reflectance; ChloAb: slightly; RE: short and drained centres with immersed sedges and Sphagnum sp., (

Class 12 : relatively dry surface; dwarf shrubs and grasses

Class 1 and 2: fluvial sand banks; barren to vegetated

Class 13: slopes of thermokarst basin, very dry and hummocky; Dryas sp., sedges, mosses

Class 10: wet areas, thermokarst basin with polygons and ponds; sedges, mosses, few Salix sp. Class 11: moist areas with indistinct polygonal structures, little surface water; Salix sp., sedges, mosses

Class 5: shallow water, densely vegetated, marshy $750 \mathrm{~nm}$; NIR: decreasing curve down to $920 \mathrm{~nm}$; SWIR: slightly bell-shaped curve; WaAb: very deep

VIII 1st MaRe: $26 \%$ at $1300 \mathrm{~nm}$; very flat, low, increasing curve in VIS and NIR; ChloAb: no; RE: no; SWIR: distinct cellulose absorption features; WaAb: no

IX 1st MaRe: 23\%-33\% at $1100 \mathrm{~nm}$; VIS: green reflectance shows local maxima, low decrease to red reflectance; ChloAb: distinct and deep; RE: distinct, bend at $740 \mathrm{~nm}$; NIR: decreasing curves down to $920 \mathrm{~nm}$, SWIR: very slightly curved; WaAb: relatively deep

River banks dominated by driftwood mark the seasonal and episodic floodplains

Higher non-flooded areas, often low-centred polygonal structures in different occurrence, vegetation is dominated by grasses, dwarf shrubs, herbs and mosses, poorly drained sites dominated by immersed sedges, drier sites dominated by

Salix sp., closed vegetation cover, active-layer depth depends on drainage and vegetation: $30-60 \mathrm{~cm}$

Higher floodplains, episodically flooded, relatively dry to very Class 8: upper floodplain;

X 1st MaRe: $34-37 \%$ at $1130 \mathrm{~nm}$; VIS: increasing curve to local maximum in red reflectance, decrease in green reflectance; ChloAb: slight, indistinct; RE: short, bend at $730 \mathrm{~nm}$; NIR increasing curve; SWIR: intimated cellulose absorption features; WaAb: none at 930-1030 nm to slightly at 1120 $1240 \mathrm{~nm}$

XI 1st MaRe: $25-30 \%$ at $1140 \mathrm{~nm}$; VIS: local maximum in green reflectance region, decrease to the red pigment region; ChloAb: deep; RE: steep with distinct bend at $740 \mathrm{~nm}$, NIR: horizontal; SWIR: slightly bell-shaped curve; WaAb: slight

XII 1st MaRe: $51 \%$ at $1100 \mathrm{~nm}$; VIS: increasing curve to high local maximum in red reflectance with a dip in green reflectance ChloAb: deep; RE: high, bend distinct at $750 \mathrm{~nm}$; NIR: decreasing curve down to $920 \mathrm{~nm}$; SWIR: high peaked bellmoist areas, very flat relief vegetated by grasses, sedges, Salix sp. and mosses, closed vegetation cover, growth height: on average $30-40 \mathrm{~cm}$, active-layer depth average $35-40 \mathrm{~cm}$ dominated by Salix sp., sedges and mosses

Seasonal floodplains, moist, poorly drained surfaces, sedges, mosses, Salix sp. and Eriophorum sp., fragmentary cover (5080\%), growth height: 30 cm, active-layer depth: 50-60 cm

Class 6: lower floodplain and wet valley floors of the 3rd terrace

Seasonal floodplains dominated by reddish Arctophila sp., very moist areas, vegetation cover: $80-90 \%$, growth height:

Class 7: lower floodplain, seasonally $>60 \mathrm{~cm}$, active-layer depth: $70-80 \mathrm{~cm}$ inundated; dominated by Arctophila sp. shaped curve; WaAb: relatively deep

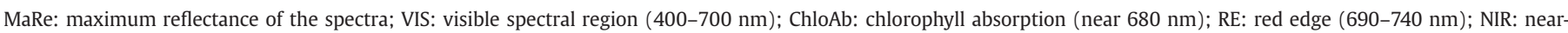
infrared spectral region (800-1300 nm); SWIR: short-wave infrared spectral region (2000-2400 nm); WaAb: water absorption (at 930-1030 nm and 1120-1240 nm).

Twelve different spectral surface classes (numbered using Roman numerals) could be extracted from the field spectra (Fig. 4). The good spectral separation indicates significant differences in surface properties between the three terrace levels of the Lena Delta. Furthermore, it was possible to spectrally separate smaller land-cover units typical of periglacial landscapes (e.g. polygonal structures). The most important factors determining spectral separability are the type of vegetation communities and vegetation vitality; both are strongly influenced by soil moisture and micro-geomorphological conditions at individual sites. The differences in these vegetation properties result in varying water, chlorophyll, or cellulose absorption features, and thus specific reflectance characteristics (Table 3 ). The reflectance shapes of the spectral signatures vary, especially in the VIS (400-700 nm) and NIR $(700-1300 \mathrm{~nm})$ regions. The spectra shapes in the SWIR2 region (2000-2400 nm) differ generally due to the cellulose absorption features of dry plant material. Differences in the red edge (690$740 \mathrm{~nm}$ ), characterizing the chlorophyll concentration, were representative of plant vitality.

Applying the continuum-removal technique for the field-spectral classes allowed a detailed differentiation of the spectral absorption 

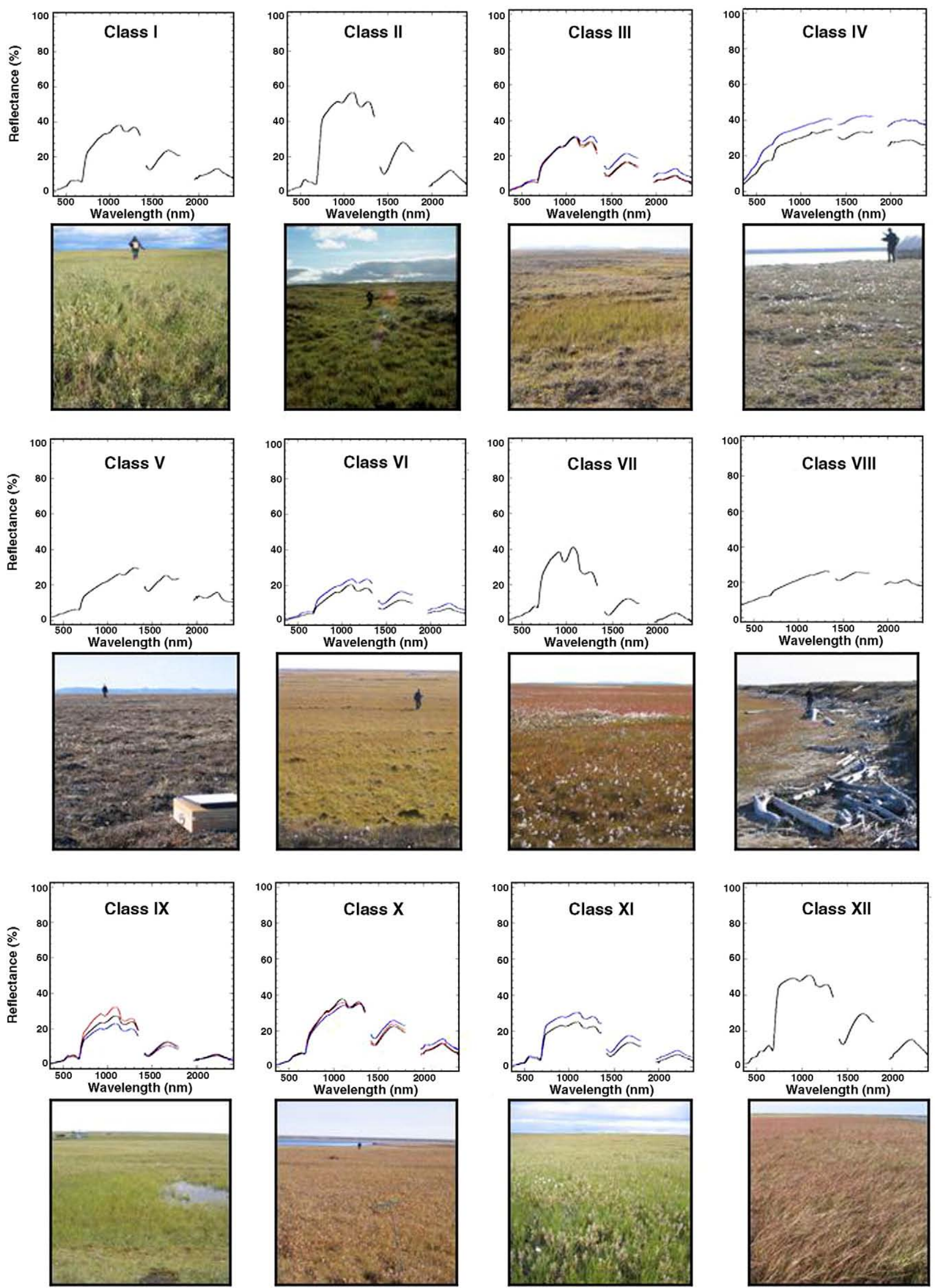

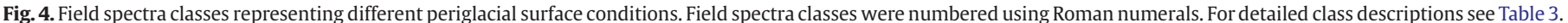


A

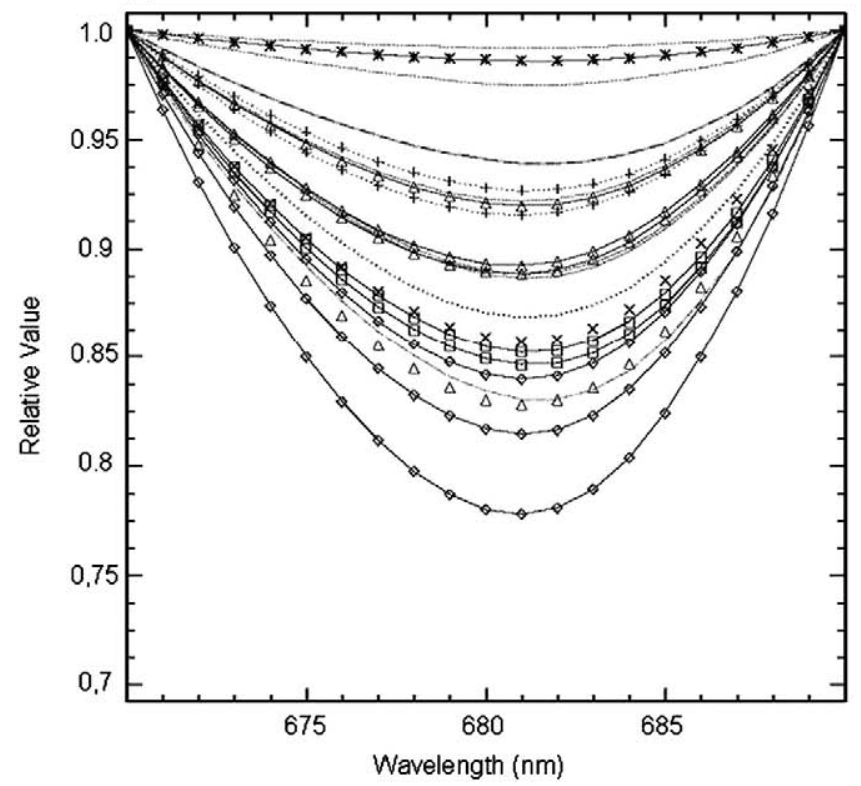

B

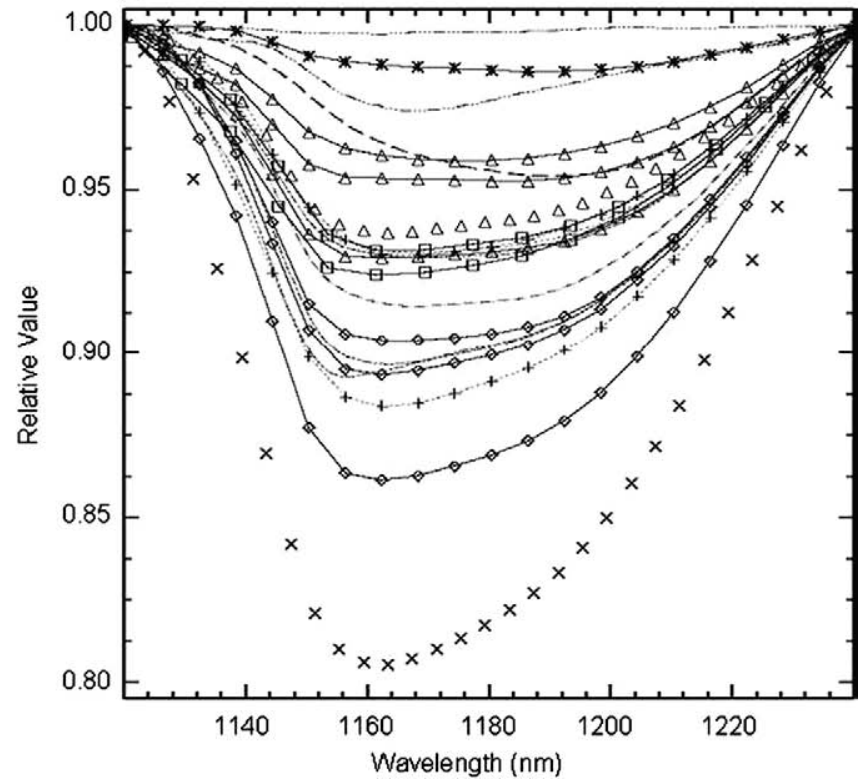

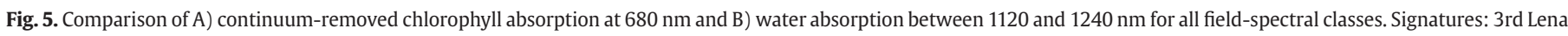

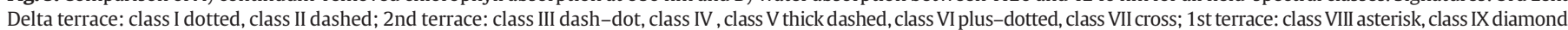
class X triangle-line, class XI square, class XII triangle.

features. The results indicate significant differences in surface conditions and vegetation cover at the individual sites. The deepest chlorophyll absorptions (Fig. 5A) are recognizable in classes II, IX, XI, and XII, and represent surfaces with fast-growing fresh grass and sedge-dominated vegetation. These classes represent the higher and lower floodplains of the first Lena Delta terrace and a recently-drained thermokarst lake depression of the third terrace. They consist of unstable or young surfaces with a more-or-less constantly-changing accumulation regime and generally very wet hydrological conditions. However, class IX spectra show heterogeneous absorption depths. The spectra representative of the main third terrace surface (class I) and the marshy lake (class VII) also show deep chlorophyll absorptions. Medium chlorophyll absorption depths represent the spectra of classes III, V, VI, and X, probably connected with the advanced phenological age of the Salix sp. in some places as well as with the tundra vegetation composition resulting from poor drainage (classes III, VI, X) or dryness (class V) at the sites. These classes consist of polygonal structures and diverse parts of thermokarst depressions on the second terrace, as well as episodically-flooded areas of the first terrace. Larger differences in absorption depths exist within classes III and X. The spectral signatures of classes IV (dry sand banks) and VIII (driftwood-dominated river banks) indicate insignificant chlorophyll absorption. In both classes major chlorophyll absorption is absent because live vegetation is not prevalent on these surfaces.

The deepest water absorption, between 1120 and $1240 \mathrm{~nm}$ (Fig. 5B), exists in spectra class VII along with Sphagnum sp., generally high plant water content, and wet surface conditions in the marshy lake. Deep but heterogeneous water absorption is also recognizable in class IX (higher non-flooded areas). Surface spectra of this class are influenced by moist surface conditions with numerous low-centre polygon ponds. The polygonal tundra (class III) and thermokarst depressions (class VI) of the second Lena Delta terrace are also characterized by sporadically moist surface conditions; i.e. these spectra classes are characterized by heterogeneous medium to deep water-absorption bands. The considerable absorption depth of class II (thaw depression, 3rd terrace) is probably connected with the high water content of fresh tall grasses growing in nutrient-rich sediments of a recently-drained lake, despite well-drained surface conditions. Seasonal and episodic floodplains characterize classes XI, XII, and X which reveal medium to low water-absorption depths. Surface conditions of these classes vary from well-drained to poorly drained with surface water. In spite of moist conditions, in some places the spectral signatures are probably more influenced by leaf water content and the advanced phenological stage of Salix sp. in the local vegetation composition. Class I is characterized by relatively dry surface conditions on the 3rd terrace, and thus also slight water absorption. Low water absorption is representative of classes IV and VIII, reflecting the very dry surface conditions of sand banks and driftwooddominated river banks. Finally, the low-water absorption of slope surfaces along a thermokarst depression (class V) was caused by the homogeneous distribution of dry mosses and lichens and dry sandy soils at these sites due to good slope drainage.

\subsection{Land-cover classification of the Turakh study site}

The Landsat ETM + classification consists of 15 main classes (numbered using Arabic numerals) resulted from training sites derived from our detailed field knowledge (Fig. 6). Additionally, after analysing the unsupervised classification results we differentiate water classes from classes for vegetated or barren fluvial sand banks. The classification covers each geomorphological terrace of the Lena Delta in the Turakh study area $\left(201.4 \mathrm{~km}^{2}\right)$. The Landsat classification indicates a good spectral separation of geomorphological landscape units and their specific periglacial surface conditions in the Lena Delta. The classification also reveals spectral characteristics of various periglacial features on a sub-terrace level, like river sand banks, sand dunes, thermokarst depressions and their slopes, overgrown ponds, floodplain areas, and thermo-erosional valleys. Moist and wet surface classes with relatively low reflectance values dominate the study area. Only about one-third of the entire area is covered by drier surface classes with generally higher reflectance values in the satellite image, represented by land-cover classes 1, 2, and 12-15.

The DEM-derived geomorphological map shows the distinct character of the individual Lena Delta terraces (Fig. 3B). Whereas the low-lying 1 st terrace units are spread out along the river channels, the 2 nd and 3rd terraces consist of more compact areas. The second terrace is dominated by strongly NNE-SSW-oriented thermokarst basins and lakes (53\%). Other major features on the 2nd terrace 

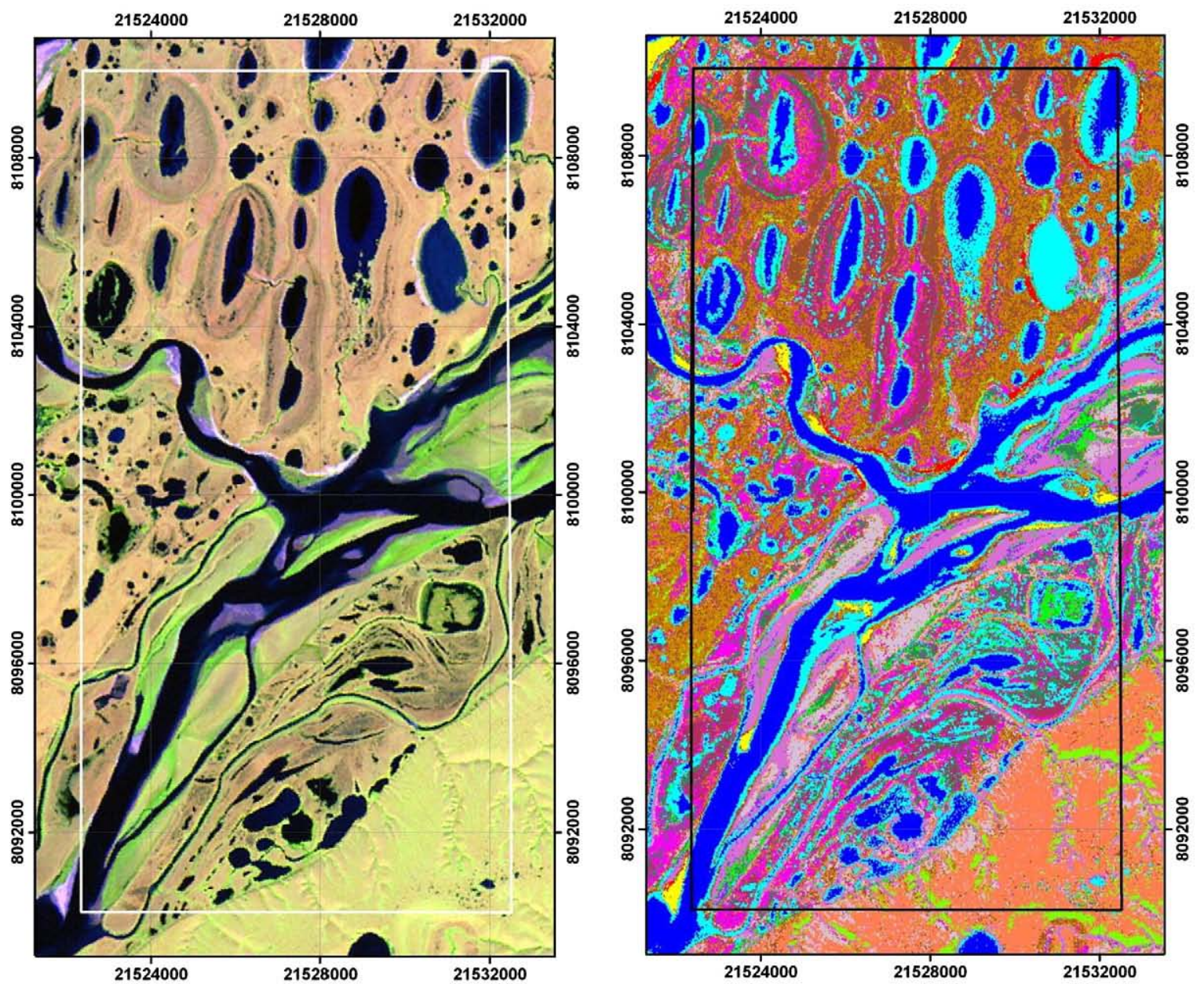

Class Area (\%) Description

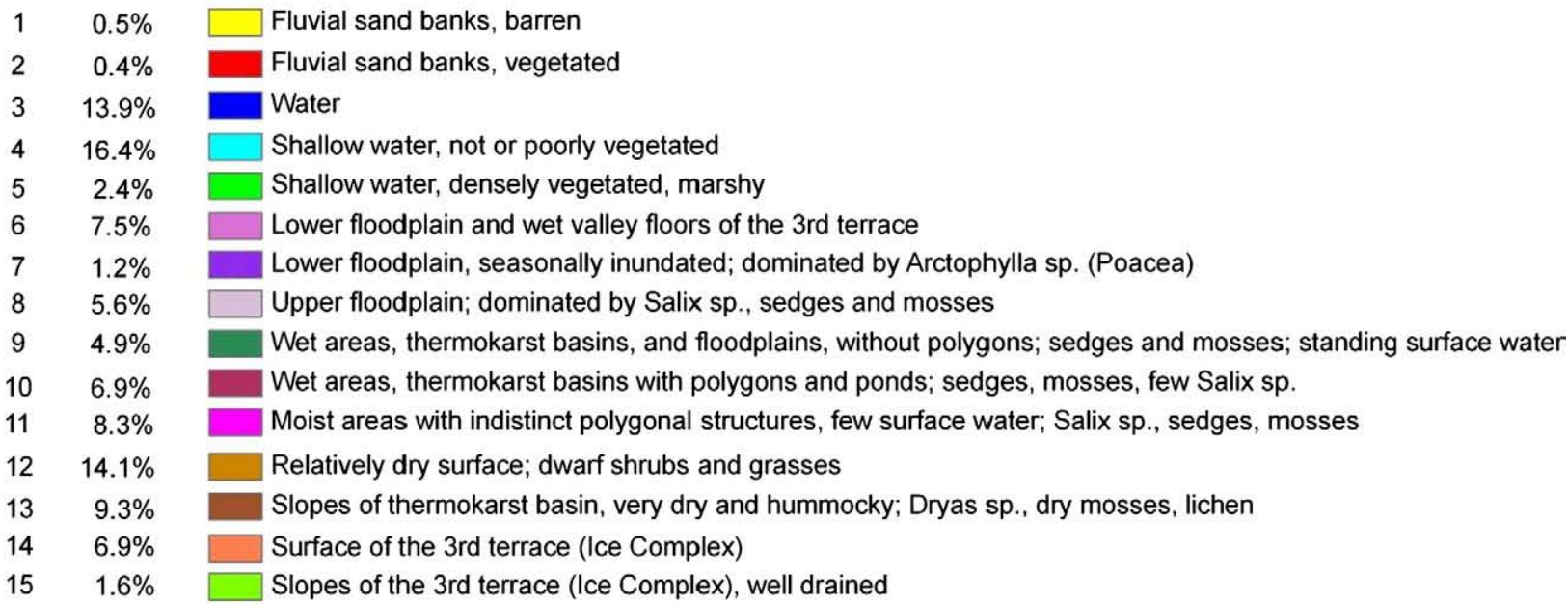

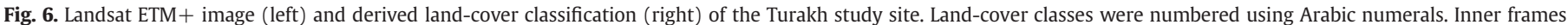
indicate the area of the DEM in Fig. 3 and the area used for calculating class distribution. Map projection: Gauss-Krüger zone 21, Pulkovo 1942.

include U-shaped thermo-erosion valleys and the wide slopes of thermokarst basins. In contrast, on the 3rd terrace thermo-erosion valleys are mostly V-shaped, and the sparsely-distributed thermokarst basins show a smaller degree of orientation.

Based on the geomorphological map units, the distribution of landcover classes was calculated for the individual Lena Delta terraces (Fig. 7). The class distributions indicate the geomorphological differences and characterize the main units at the Delta study site.
In general, the 1 st terrace is dominated by moist and wet surface classes $6,7,8$, and 9, indicating active fluvial-deltaic processes. On the contrary, most of the 2nd and 3rd terraces are characterized by the drier surfaces of classes 12,13, and 14. Both terraces are much older than the 1st terrace (Schirrmeister et al., 2003). On both terraces the occurrence of thermokarst is an important causal factor for the presence of moist and wet land-cover units. The bottoms of the large thermokarst depressions are often moister than the surrounding 

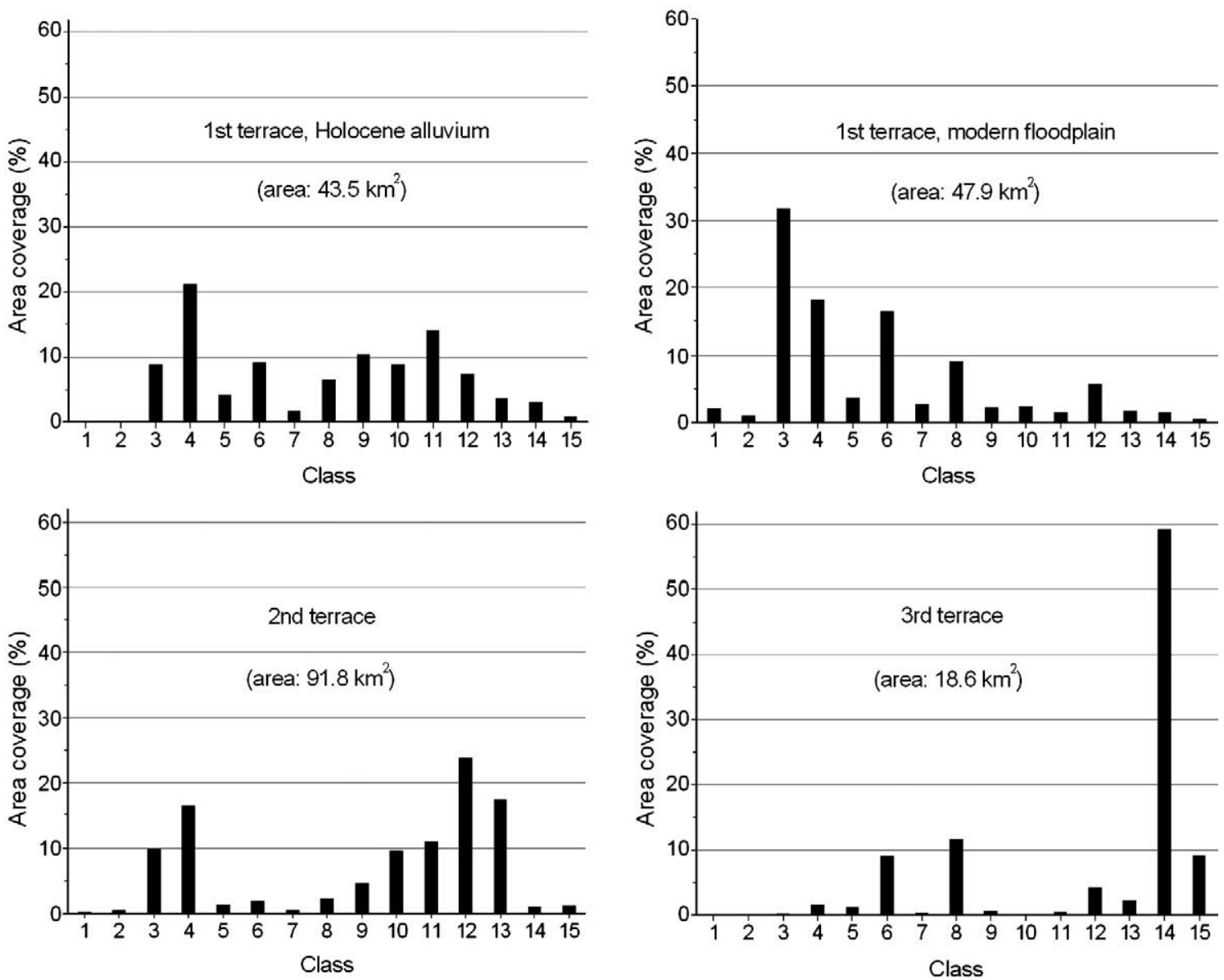

Fig. 7. Calculated distribution of Landsat-derived land-cover classes for the main geomorphologic units at the Turakh study site.

uplands, because drainage is lacking and active-layer depths are shallow. The basins usually contain many low-centre polygons with ponds (classes 10 and 11) and large, oriented thermokarst lakes. The drainage on the 3rd terrace often results in characteristically wet thermo-erosional valleys and ravines (Fig. 3B). On both terraces, steeper slopes along elevated uplands feature relatively well-drained surfaces. In some poorly drained upland areas many small ponds occur, possibly indicating the initiation of thermokarst formation in these areas.

\subsection{Pedological map of a thermokarst basin}

In addition to the Landsat classification, a hyperspectral CHRISProba image and a field pedological survey was used for soil mapping to better understand spatial distribution of soil types within thermokarst depressions on the 2nd Lena Delta terrace (Fig. 8). The 17/11/04 CHRIS-Proba RGB composite was chosen for mapping because spectral band 17 is located on the major water-absorption band, band 11 on the red-edge region, and band 4 on the green vegetation reflectance peak.

The thermokarst depression is part of the typical relief of the 2nd Lena Dalta terrace characterized by widespread, ellipsoidal, and roughly NNE-SSW-oriented thaw lakes and basins (see also Morgenstern et al., 2008). The studied depression is ca. $4.5 \mathrm{~km}$ long by $1.5 \mathrm{~km}$ wide and contains two remnant thermokarst lakes interconnected by a small channel. The lakes have broad, $\mathrm{ca}$. $1 \mathrm{~m}$ deep submerged shelves and a central basin up to $10 \mathrm{~m}$ deep (see lakes in Fig. 6: land-cover classes 3 and 4 ). The main basin floor sits about 6-8 m below the surrounding uplands, resulting in a total thermokarst subsidence of 16-18 $\mathrm{m}$ for the surveyed basin (Lantuit et al., 2007). The lakes are also connected via an outflow to a main delta channel to the south Driftwood on the basin floor and water distribution in a June 1964 Corona satellite image indicate that during the spring ice breakup the outflow is reversed because water levels increase by several meters in the main channel and parts of the basin are temporally inundated. In the subaerial part of the basin close to the lakes, sand dunes are partially stabilized by vegetation. The surface between dunes and marginal basin slopes is characterized by moist-to-inundated sedge tundra; ice-wedge polygon ridges are distinguishable. The basin slopes are very well-drained and consist of dry sandy surfaces with slope angles between 8 and $15^{\circ}$. The initiation of a similar lake-basin system nearby (Lake Nikolay, same delta terrace, ca. $40 \mathrm{~km}$ to the NNE) has been dated by Andreev et al. (2004) to the early Holocene (about 10,300 cal. yr BP).

Based on general knowledge about the influence of soil type on surface drainage and vegetation cover, we were able to map the probable distribution of soils from CHRIS-Proba spectral information. The map contains five pedological units (Typic Psammorthel, Typic Psammoturbel, Psammetic Aquorthel, Typic Fibristil, and a complex consisting of Glacic or Typic Aquiturbel and Typic Aquorthel or Typic Histoturbel) named according to the US Soil Taxonomy (Soil Survey Staff, 2003). The soil classes are concentrically arranged within the thermokarst depression (Fig. 8), accurately reflecting the relief and drainage situation (i.e. soil moisture) and, therefore, changes of the vegetation cover as well. In general, all investigated soils consisted of fine to coarse-grained sand and showed more-or-less strong signs of cryoturbation and redox reaction. The soil organic carbon increases from the slope towards the lake. Carbon/Nitrogen $(\mathrm{C} / \mathrm{N})$ ratios increase with decreasing carbon decomposition inside the soil profiles as well as within the catena. The $\mathrm{pH}$ values of all soils range between 4 


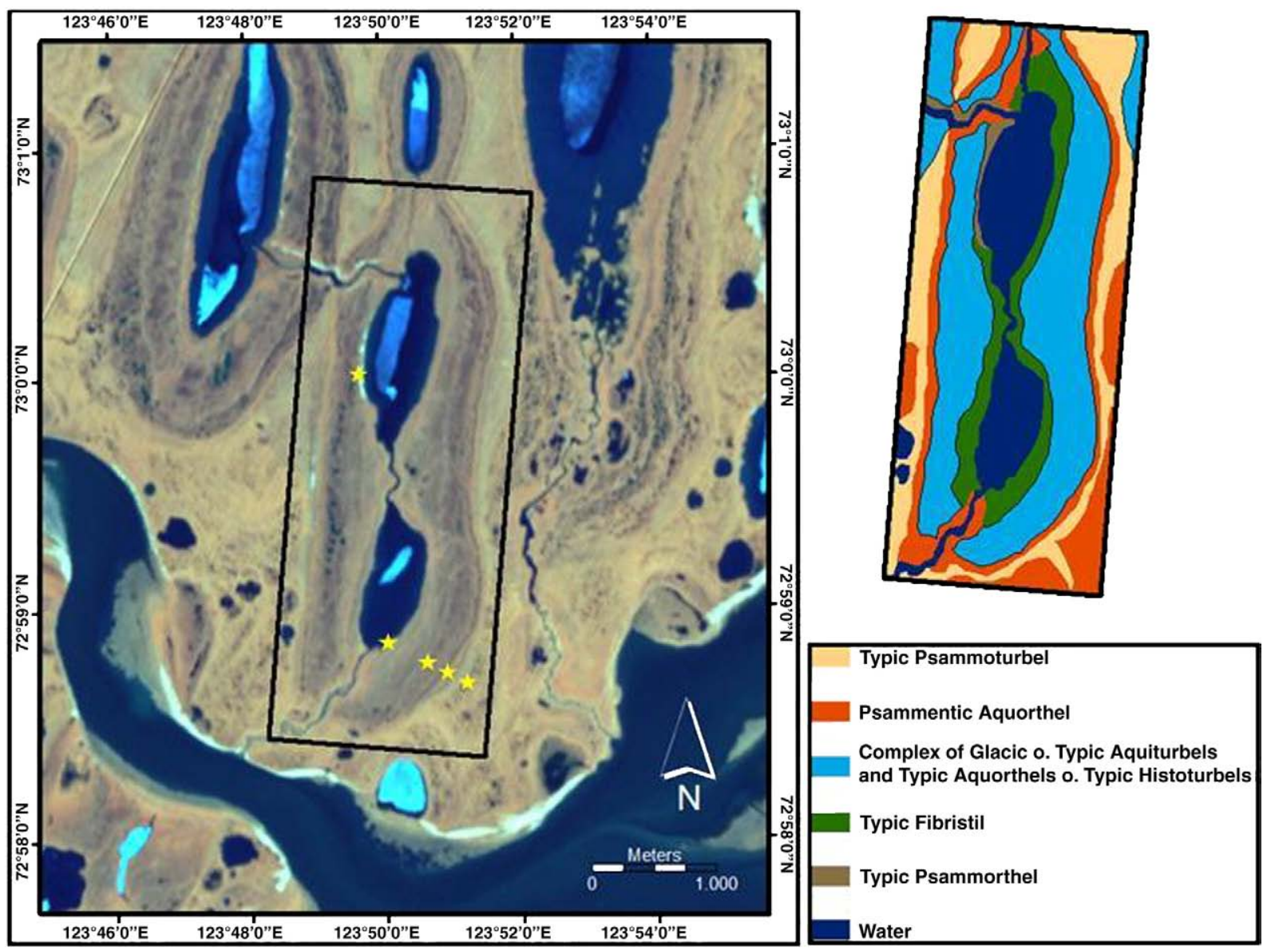

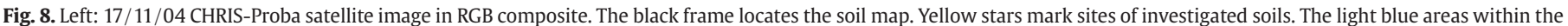
dark blue water bodies are residues of ice cover at the end of June. Right: Soil map for a typical thermokarst depression on the 2nd Lena Delta terrace.

and 5 and nitrogen contents are low in all samples (Table 2). The soils clearly vary in their drainage situations according to the relief level and slope inclination. The well-drained slopes of the thermokarst depression represented by lime-green colours in the CHRIS-Proba image are dominated by Typic Psammoturbels based on fluvial fine-to-mediumgrained sands. These poorly-developed soils have a very low organic content $\left(0.2-2.5 \% \mathrm{C}_{\text {org }}\right)$ and an active-layer depth of $65-80 \mathrm{~cm}$. Strong solifluction and cryoturbation processes resulted in the formation of the typical hummocky surface on upper slopes (see Fig. 4, class V). Farther down the slope the drainage conditions worsen, resulting in the presence of Psammetic Aquorthels $\left(0.2-1.4 \% \mathrm{C}_{\mathrm{org}}\right)$. Because of similar pedological conditions, the uplands surrounding the depression, represented by greyish-green colours in the CHRIS-Proba image (Fig. 8), are assumed to also consist predominantly of this soil type. The very wet bottom of the thermokarst depression (dark-greyish colours) consists of an indistinct to distinct polygonal micro-relief covered by a heterogeneous soil complex of Glacic or Typic Aquiturbels, and Typic Aquorthels or Typic Histoturbels. The Typic Aquorthels (up to $4.5 \% \mathrm{C}_{\mathrm{org}}$ ) and Typic Histoturbels are situated in poorly drained centres of lowcentre polygons characterized by water levels at the soil surface and active-layer depths around $30 \mathrm{~cm}$. In some places, accumulated organic material formed peat horizons. The more elevated polygon rims are composed of Glacic and Typic Aquiturbels, and characterized by a distinctly deeper water table, less accumulation of organic matter, and cryoturbation features. The lowermost parts of the thermokarst depression close to the lakes were dominated by wet Typic Fibristils based on peaty lake and floodplain sediments (up to $10 \% \mathrm{C}_{\text {org }}$ ). The alteration of peat and mineral horizons indicates periodic flooding of the thermokarst lake shore. In comparison, surface conditions are drier due to the lack of low-centre polygons, indicated by brighter grey colours in the CHRIS-Proba image. Along steep erosional cliffs and especially on the western shore of the northern lake, poorly-developed soils (Typic Psammorthel) were located in a sand dune setting typical of some 2 nd terrace areas. These soils are easily visible due to the high reflectance of sand (white colours).

\section{Discussion}

\subsection{Characterization of periglacial surface features by field spectrometry}

The field spectra classes, based on spectral properties of periglacial surfaces, vary considerably between the Lena Delta terraces. The surface conditions of the terraces are determined by their geomorphological, hydrological, and pedological situation as well as the vegetation cover. The most important factors influencing the spectral signatures are the type and the state of the vegetation cover, which in turn are determined largely by these surface conditions and elucidated in the VIS and NIR spectra shapes. Thus, the characterization and analysis of spectral signatures, general-reflectance properties, and absorption features offer information about the individual surface characteristics and allow the spectra to be classified into specific surface classes (Fig. 4, Table 3). We consider the spectra from the tundra landscapes of the Lena Delta to be a mixed signal of vegetation, soils, and moisture (soil or surface).

Most acquired spectra show low general-reflectance values, probably due to both the high surface-moisture content in the Lena Delta and a decrease in vegetation vitality which had already begun during the spectra acquisition in late summer (e.g. classes VI and X). Distinctly low reflectance associated with dry or dead vegetation is recognizable in classes V and VIII, which are additionally characterized 
by very dry surface conditions. However, the general reflectance also depends on the percentage vegetation cover at individual sites. In case of very moist surface conditions, the reflectance is not decreased if a closed vegetation cover dominates the general reflectance. For instance, classes VII and XII show high reflectance values even under moist to very moist surface conditions. When the vegetation cover is decreased, the wet soil surface or the presence of surface water reduces the total reflectance (e.g. Weidong et al., 2002). Some of our field spectra show a low reflectance despite high vegetation vitality, which is possibly related to the very moist surface conditions on-site (e.g. classes IX and XI) and also to a low percentage vegetation cover (e.g. class XI). Soil reflectance increases with decreasing vegetation cover for dry soils as suggested by e.g. Pinker and Karnieli (1995), and is observed here in dry elevated sandbanks which differ in vegetation cover (class IV).

Specific vegetation properties can be evaluated from individual absorption features and local maxima or minima, especially in the VIS and NIR regions of the field spectra. Spectra indicating high vegetation vitality (e.g. classes II, VII, and XII) are characterized by deep chlorophyll absorptions (Fig. 5A) and high and steep red-edge slopes with a drop at 740-750 nm (Fig. 4), indicating a relationship between red-edge shape and chlorophyll concentration, and thus plant vitality (Curran et al., 1990; Horler et al., 1983; Pinar \& Curran 1996; Rock et al., 1988). In contrast, a short or gentle red-edge bending around $730 \mathrm{~nm}$ is correlated with medium-to-low chlorophyll absorption; this signature is typical of classes V, VI, and X. The reflectance in the red-edge region is not significantly influenced by background surface conditions, so the red-edge characteristics can be attributed solely to the vegetation cover (Horler et al., 1983). According to Elvidge (1990), spectra with high green reflectance and deep pigment absorption in the VIS range as well as deep chlorophyll absorption characterize surfaces with fresh green vegetation (e.g. classes II and XI). The spectra from surfaces with advanced phenological vegetation age show decreased green reflectance, poor chlorophyll absorption, and therefore an increased red reflectance in the VIS as well as stronger cellulose absorption features in the SWIR2 (2000-2400 nm). Exceptional cases are classes VII and XII with distinctly increasing curves in the VIS despite the high vitality of local vegetation. This is probably associated with the plant pigmentation of the reddish Arctophila sp. on wet sites (Fig. 4). Additionally, all spectra characterized by vegetation cover with high vitality show generally down-sloping curves in the NIR from $920 \mathrm{~nm}$ towards the long wavelengths.

The surface moisture and drainage conditions at the field spectra study sites were evaluated using the continuum-removed waterabsorption bands between 1120 and $1240 \mathrm{~nm}$ (Fig. 5B), general reflectance of the spectra, and field knowledge of the sites. Evaluation of hydrological surface conditions from water-absorption bands only is critical, because these spectral segments are also strongly connected with leaf water content (Elvidge, 1990; Pu et al., 2003). This challenge is exemplified by class VI, where water-absorption depths are comparably low (Fig. 5B). Only the generally-low reflectance curve indicates the very moist to wet surface conditions typical of thermokarst depressions of the 2nd Lena Delta terrace (Fig. 4). In contrast, spectra acquired in a thermokarst basin on the 3rd terrace (class II) show strong water absorption (Fig. 5B). The relative surface dryness at this site, caused by the recent (between 1980 and 2000) complete drainage of the local thermokarst lake, is only recognizable in the high general reflectance of the spectra (Fig. 4). Harris et al. (2005) suggested relationships between NIR water-absorption features of Sphagnum sp. and hydrological conditions in northern peatlands. In accordance with this result, the spectra of a marshy lake (class VIII) on the 2nd terrace vegetated with Arctophila sp. and Sphagnum sp. show strong water absorption.

In summary, the application of field spectrometry clearly offers the opportunity to identify typical micro- to meso-scale variability of arctic periglacial landscapes occurring in the Lena Delta.

\subsection{Geomorphological characterization from remote-sensing data}

The result of the Landsat ETM+ classification at the Turakh study site in the western Lena Delta consists of 15 land-cover classes, which differ in vegetation cover, drainage situation, and periglacial and geomorphological features (Figs. 6 and 7). The land-cover classification was guided by detailed information collected with a field spectrometer and descriptive field data on land-cover (Ulrich \& Grosse, 2007). For instance, the observed field-spectral differences between periglacial structures (e.g. polygonal structure characteristics, thaw depression units) could be used to refine several Landsat landcover classes (e.g. classes 9, 10,11). Furthermore, knowledge of the detailed field-spectral properties of the Lena Delta terraces was useful for a finer differentiation of the units in the Landsat classification (e.g. sub-terrace levels, fluvial sand banks, thermo-erosional valleys). Finally, we derived comparable results for the field-spectral classification and the Landsat classification, both indicating the good spectral separation of the periglacial features and terraces in the Lena Delta (Table 3). Additionally, CHRIS-Proba pedological mapping was helpful for better discrimination of thermokarst depression surface properties (Fig. 8).

Comparable land-cover classifications for northeast Siberian study sites were applied by Grosse et al. (2006) and Schneider et al. (2009). Schneider et al. (2009) developed a basic land-cover classification of the entire Lena Delta with the goal of quantifying emissions of the greenhouse gas methane from distinct land-cover units. In this study, nine classes were defined predominantly by their vegetation cover and surface moisture. Geomorphological conditions were given less consideration. The dominating distribution of wet and moist surfaces classes in the Lena Delta already suggested by Schneider et al. (2009) can be confirmed. The authors especially focused on the land-cover class 'wet-sedge and moss-dominated tundra', as these areas are a major source of methane in the delta. At our Turakh study site this class occurs predominantly within the thermokarst depressions on the 2nd terrace as well as on the Holocene alluvial plains of the 1st terrace. With our local classification, a further differentiation of their general class (wetsedge and moss-dominated tundra) was possible with classes 11, 10, 9, and 5 representing moist, very moist with polygons, very moist without polygons, and partly marshy areas, respectively (Fig. 6). These four classes differ mainly in the type and character of polygonal structures and drainage conditions, both important parameters for accurately quantifying methane emissions (Wagner et al., 2003).

The Turakh study site (Figs. 3 and 6) shows differences in distribution of thermokarst depressions for each delta terrace. Large thermokarst depressions several $\mathrm{km}$ in diameter cover about $53 \%$ of the 2nd terrace (Fig. 3B). The 3rd terrace with its ice-rich Ice Complex deposits shows only limited thermokarst in the studied image subset. This stands in contrast to many other Ice Complex regions in the North Siberian lowlands with often more than $50 \%$ of the area impacted by thermokarst (Grosse et al., 2005, 2006).

A possible cause could be the better drainage of the Ice Complex erosional remnants of the 3rd terrace in the delta, especially in the study area subset. The 3rd terrace unit is surrounded by delta channels and heavily incised by thermo-erosional valleys draining the uplands and hampering the formation of extended thermokarst lakes and basins (Fig. 3B). The general picture of thermokarst lake distribution in the study area agrees with data on overall lake distribution in the entire Lena Delta (Morgenstern et al., 2008). Peat soils investigated within the depressions on the 2nd terrace (Fig. 8) are linked to surface stabilization that followed Holocene thermokarst disturbance and provided the conditions for stable peat growth (Galabala 1987; Grigoriev, 1993). The thermokarst depressions in the Turakh study site are predominantly covered by land-cover classes 10 and 11 represented by moist and very moist surface conditions, contrary to the adjacent uplands of the 2 nd terrace which are covered predominantly by classes 12 and 13 (Figs. 6 and 7). The presence of hydromorphic 
soils, polygonal tundra, and sedge and moss vegetation in these depressions indicates high methane emission potential (Pfeiffer et al., 2002; Wagner et al., 2003). However, actual methane emission is affected by numerous factors, e.g. soil temperature, water level, vegetation cover, $\mathrm{pH}$-value, active-layer depth, soil organic-carbon content, and the composition of the soil microbial communities (e.g. Sachs et al., 2008; Wagner et al., 2003).

General classification uncertainties are caused by possible surface class misclassifications caused by mixed pixels consisting of at least two different land-cover classes. Such pixels, characterized by mixed spectral signatures, are likely to be classified to a wrong land-cover class (Richards \& Jia, 1999). Another uncertainty is caused by the limited availability of field data for this large, remote study area, which may result in the inadequate description of classes or the unrecognized presence of other land-cover types. Such misclassification probably occurs to some extent in class 8 (upper floodplain) and class 6 (lower floodplain and wet valley floors of the 3 rd terrace). Although difficult because of the probably-similar plant communities in these classes, a more detailed assessment of the floodplain characteristics along the river channels and in the thermokarst basins might result in enhanced class differentiation, and possibly also a better separation of these wetland-cover classes between the Lena Delta terraces.

Class 15 (well-drained slopes of the 3rd terrace [Ice Complex]) is characterized by a high reflectance which was interpreted and verified in the field as relatively well-drained, dry slopes with south-facing exposure and accordingly different vegetation communities and vitality. However, the high reflectance of these steep slopes could partially be a result of their exposed position, and thus the sensor viewing and illumination geometry. Another factor is the strong variation of geomorphological and hydrological conditions of the polygonal micro-relief that is not recognizable at the $30 \mathrm{~m}$ Landsat resolution. Simultaneous acquisitions of multi- or hyperspectral remote-sensing data and field-spectral measurements will be needed to directly compare and upscale field spectra. Good classification accuracy is expected for classes 12,13 , and 14 , all represented by drier surfaces. Adequate accuracy is indicated by good accordance of the classified land-cover distribution with the expected spatial distribution of these classes on the Lena Delta terraces from field knowledge. Comparison of the Landsat ETM+ land-cover classes with soil mapping field descriptions from more intensively-studied sites (Fig. 8) and field spectra acquisitions (Fig. 4) indicates a good initial accuracy for the classified land cover. A full quantitative accuracy assessment of the land-cover classification (e.g. Congalton, 1991) was not achieved because site replication was lacking due to difficult field logistics in this remote Arctic region.

\section{Conclusions}

Field spectrometry allowed a spectral differentiation of integrated landscape-scale characteristics typically emerging in vegetation, water, and soils of periglacial lowlands. Differences of individual landscape units in the delta are predominantly caused by vegetation composition, vegetation vitality, and soil and surface moisture in various micro- to meso-scale landscape units like ice-wedge polygonal nets, thermokarst depressions, slopes, thermo-erosional valleys, or well-drained uplands. Distinctive surface properties can be characterized by and related to the shape of the spectral curve, i.e. general reflectance, red edge around $690-740 \mathrm{~nm}$, reflectance minima and maxima, and significant absorption features like that for chlorophyll at $680 \mathrm{~nm}$ and for water at 1140-1220 nm. Besides visual grouping, the continuum-removal technique was successfully applied to differentiate between individual spectral signatures.

The point acquisition of field-spectral properties in high spectral and spatial resolution from periglacial features allows the interpretation of coarser resolution satellite data to be validated. The analysis of fieldspectral data in combination with geomorphological, pedological, and vegetation data guided the characterization and classification of periglacial surfaces and land-cover units in the Lena Delta. The field dataset provides the basis for further spectral investigations (field spectrometry, multi- and hyperspectral satellite data) in the Arctic tundra. The characterization of periglacial surface types derived from both field spectra and Landsat 7 satellite data by analysing the spectral composition and spatial distribution of the individual classes indicates significant differences in surface properties between the three main delta terraces, and thus a good spectral separation of these units. This implies that larger-scale mapping of Arctic deltaic units is possible with these techniques.

Further investigations should consider seasonal and long-term variations in spectral signatures, providing a basis for detecting and evaluating environmental changes in the periglacial landscapes of a warming Arctic. This local study will help in the efforts to calculate a delta-wide methane emission balance using remote sensing and modeling (Landsat-7: Schneider et al., 2009; MERIS: Kirschke et al., 2008). Finally, the achieved spectral dataset will serve as a starting point for ongoing and future land-cover and change-detection studies with various multi- and hyperspectral sensors in this climate-sensitive Arctic wetland.

\section{Acknowledgements}

Field work was carried out within the framework of the RussianGerman expedition Lena 2005. We thank all colleagues involved in the logistical and scientific support. We would like to thank Birgit Heim for fruitful discussions on field spectrometry and multi- and hyperspectral remote-sensing applications. The continuing effort and support of the European Space Agency (ESA) and SIRA electrooptics Ltd. (UK) to provide the CHRIS-Proba data is gratefully acknowledged. We appreciate the detailed and valuable comments of three anonymous reviewers that improved this article.

\section{References}

AG Boden (1994). Bodenkundliche Kartieranleitung (pp. 392)., 4th ed. Stuttgart E. Schweizerbart`sche Verlagsbuchgesellschaft (in German).

ACIA (2005). Arctic climate impact assessment. Cambridge University Press 1042 pp.

Andreev, A., Tarasov, P., Schwamborn, G., Ilyashuk, B., Ilyashuk, E., Bobrov, A., et al. (2004). Holocene paleoenvironmental records from Nikolay Lake, Lena River Delta, Arctic Russia. Palaeogeography, Palaeoclimatology, Palaeoecology, 209, 197-217.

Are, F., \& Reimnitz, E. (2000). An overview of the Lena River Delta setting: Geology, tectonics, geomorphology and hydrology. Journal of Coastal Research, 16, 1083-1093.

Boike, J., Wille, C., \& Abnizova, A. (2008). Climatology and summer energy and water balance of polygonal tundra in the Lena River Delta, Siberia. Journal of Geophysical Research, 113. doi:10.1029/2007JG000540

Boike, J., \& Yoshikawa, K. (2003). Mapping of periglacial geomorphology using kite/ ballon aerial photography. Permafrost and Periglacial Processes, 14, 81-85.

Brown, J., Ferrians, O. J., Jr., Heginbottom, J. A., \& Melnikov, E. S. (1998). Circum-arctic map of permafrost and ground ice conditions. In M. Parsons \& T. Zhang (Eds.), International Permafrost Association Standing Committee on Data Information and Communication. Circumpolar Active-Layer Permafrost System, Version 2.0Bolder, Colorado. National Snow and Ice Data Center/World Data Center for Glaciology. CDROM, 2003.

CAVM Team (2003). Circumpolar Arctic Vegetation Map, Scale 1:7.500.000. Conservation of Arctic Flora and Fauna (CAFF) Map No.1. U.S. Fish and Wildlife Service, Anchorage, Alaska. http://www.geobotany.uaf.edu/cavm/finalcavm/index.html

Ceccato, P., Flasse, S., Tarantola, S., Jacquemoud, S., \& Gregoire, J. M. (2001). Detecting vegetation leaf water content using reflectance in the optical domain. Remote Sensing of Environment, 77, 22-33.

Chabrillat, S., Goetz, A. F. H., Olsen, H. W., \& Krosley, L. (2002). Use of hyperspectral images in the identification and mapping of expansive clay soils and the role of spatial resolution. Remote Sensing of Environment, 82(2-3), 431-445.

Chavez, P. S. (1996). Image-based atmospheric corrections - Revised and improved. Photogrammetric Engineering \& Remote Sensing, 62(9), 1025-1036.

Clark, R. N. (1999). Spectroscopy of rocks and minerals, and principles of spectroscopy. In A. N. Rencz (Ed.), Remote sensing for the earth science - Manual of Remote Sensing (pp. 3-58)., 3rd ed. New York John Wiley \& Sons.

Clark, R. N., \& Roush, T. L. (1984). Reflectance spectroscopy: Quantitative analysis techniques for remote sensing applications. Journal of Geophysical Research, 89, 6329-6340.

Clevers, J. G. P. W., Kooistra, L., \& Schalepman, M.E. (2008). Using spectral information from the NIR water absorption features for the retrieval of canopy water content. International Journal of Applied Earth Observation and Geoinformation, 10(3), 388-397.

Congalton, R. G. (1991). A review of assessing the accuracy of classifications of remotely sensed data. Remote Sensing of Environment, 37, 35-46. 
Curtiss, B., \& Goetz, A. F. H. (1994, July). Field spectrometry: Techniques and instrumentation. International Symposium on Spectral Sensing Research, 31-40.

Curran, P. J., Dungan, J. L., \& Gholz, H. L. (1990). Exploring the relationship between reflectance red edge and chlorophyll content in slash pine. Tree Physiology, 7, 33-48.

Elvidge, C. D. (1990). Visible and near infrared reflectance characteristics of dry plant materials. International Journal Remote Sensing, 11, 1775-1795.

Etzelmüller, B., degård, R. S., Berthling, I., \& Sollid, J. L. (2001). Terrain parameters and remote sensing data in the analysis of permafrost distribution and periglacial processes: Principles and examples from Southern Norway. Permafrost and Periglacial Processes, 12, 79-92.

Everdingen, R. O. V. (Ed.). (2005). Multi-language glossary of permafrost and related ground-ice terms Calgary International Permafrost Association. http://nsidc.org/ fgdc/glossary

Frohn, R. C., Hinkel, K. M., \& Eisner, W. R. (2005). Satellite remote sensing classification of thaw lakes and drained thaw lake basins on the North Slope of Alaska. Remote Sensing of Environment, 97, 116-126.

Galabala, R. O. (1987). New data on the Lena-Delta structure. Quarternary of North-East USSR, Magadan (pp. 152-172). (in Russian).

Goryachkin, S. V., Karavaeva, N. A., Targulian, V. O., \& Glazow, M. V. (1999). Arctic soils: Spatial distribution, zonality and transformation due to global change. Permafrost and Periglacial Processes, 10, 235-250.

Grigoriev, M. N. (1993). Cryomorphogenesis in the Lena Delta (pp.173). Yakutsk (in Russian).

Grigoriev, M. N., Imaev, V. S., Imaeva, L. P., Kozmin, B. M., Kunitzkiy, V. V., Lationov, A. G., et al. (1996). Geology, seismicity and cryogenic processes in the arctic areas of Western Yakutia. Yakut Scientific Centre SD RAS, Yakutsk (pp. 84). (in Russian).

Grosse, G., Schirrmeister, L., Kunitzky, V. V., \& Hubberten, H. W. (2005). The use of CORONA images in remote sensing of periglacial geomorphology: An illustration from the NE Siberian coast. Permafrost and Periglacial Processes, 16, 163-172.

Grosse, G., Schirrmeister, L., \& Malthus, T. J. (2006). Application of Landsat-7 satellite data and a DEM for the quantification of thermokarst-effected terrain types in the periglacial Lena-Anabar coastal lowland. Polar Research, 25, 51-67.

Harris, A., Bryant, R. G., \& Baird, A. J. (2005). Detecting near-surface moisture stress in Sphagnum spp. Remote Sensing of Environment, 97, 371-381.

Hinkler, J., Ørbæk, J. B., \& Hansen, B. U. (2003). Detection of spatial, temporal, and spectral surface changes in the Ny-Ålesund area $79^{\circ} \mathrm{N}$, Svalbard, using a low cost multispectral camera in combination with spectroradiometer measurements. Physics and Chemistry of the Earth, 28, 1229-1239.

Hope, A. S., Fleming, J. B., Stow, D. A., \& Aguado, E. (1991). Tussocks tundra albedos on the north slope of Alaska: Effects of illumination, vegetation composition and dust deposition. Journal of Applied Meteorology, 30,1200-1206.

Hope, A. S., Kimball, J. S., \& Stow, D. A. (1993). The relationship between tussock tundra spectral reflectance properties and biomass and vegetation composition. International Journal Remote Sensing, 14, 1861-1874.

Horler, D. N. H., Dockray, M., \& Barber, J. (1983). The red edge of plant leaf reflectance. International Journal Remote Sensing, 4, 273-288.

Jago, R. A., Cutler, M. E. J., \& Curran, P. J. (1999). Estimating canopy chlorophyll concentration from field and airborne spectra. Remote Sensing of Environment, 68, $217-224$.

Kade, A., Romanovsky, V. E., \& Walker, D. A. (2006). The N-factor of nonsorted circles along a climate gradient in Arctic Alaska. Permafrost and Periglacial Processes, 17, 279-289.

Kirschke, S., Guenther, K. P., Wisskirchen, K., Sachs, T., \& Dech, S. (2008). Methane emission from Siberian wet polygonal tundra on multiple spatial scales: Processbased modelling of methane fluxes on the regional scale, Lena Delta. Proceedings of the Ninth International Conference on Permafrost (NICOP), June 29-July 3, 2008, Fairbanks, Alaska, USA.

Lantuit, H., Grigoriev, M. N. Grosse, G. \& Ulrich, M. (2007). Studies of oriented lakes and thermokarst depressions. In L. Schirrmeister, D. Wagner, M. N. Grigoriev \& D.Yu. Bolshiyanov (Eds.), Russian-German Cooperation SYSTEM LAPTEV SEA - The Expedition Lena- 2005Reports on Polar and Marine Research, Vol. 550 hdl:10013/ epic.26642.d001.

Milton, E. J. (1987). Principles of field spectroscopy - Review article. International Journal Remote Sensing, 8, 1807-1827.

Milton, E. J., Rollin, E. M., \& Emery, D. R. (1995). Advances in field spectroscopy. In F. M. Danson \& S. E. Plummer (Eds.), Advances in environmental remote sensing (pp. 9-32). Chichester John Wiley \& Sons

Morgenstern, A., Grosse, G., \& Schirrmeister, L. (2008). Genetic, morphological, and statistical characterization of lakes in the permafrost-dominated Lena Delta. Proceedings of the Ninth International Conference on Permafrost (NICOP), June 29-July 3, 2008, Fairbanks, Alaska, USA.

Nelson, F. E., Anisimov, O. A., \& Shiklomanov, N. I. (2002). Climate change and hazard zonation in the circum-Arctic permafrost regions. Natural Hazards, 26, 203-225.

Okin, G. S., Roberts, D. A., Murray, B., \& Okin, W. J. (2001). Practical limits on hyperspectral vegetation discrimination in arid and semiarid environments. Remote Sensing of Environment, 77, 212-225.

Olthof, I., \& Fraser, R. H. (2007). Mapping northern land cover fractions using Landsat $\mathrm{ETM}+$. Remote Sensing of Environment, 107, 496-509.

Peddle, D. R., \& Franklin, S. E. (1993). Classification of permafrost active layer depth from remotely sensed and topographic evidence. Remote Sensing of Environment, 44, 67-80.

Petzold, D. E., \& Rencz, A. N. (1975). The albedo of selected subarctic surfaces. Arctic and Alpine Research, 7, 393-398.

Pfeiffer, E. -M., Wagner, D., Kobale, S., Kutzbach, L., Kurchatova, A., Stoof, G., et al. (2002). Modern processes in permafrost affected soils. In E. -M. Pfeiffer \& M. N. Grigoriev (Eds.), Russian-German Cooperation SYSTEM LAPTEV SEA 2000 - The Expedition LENA 2001 (pp. 21-41).
Pinar, A., \& Curran, P. J. (1996). Grass chlorophyll and the reflectance red edge, Technical note. International Journal Remote Sensing, 17(2), 351-357.

Pinker, R. T., \& Karnieli, A. (1995). Characteristic spectral reflectance of semi-arid environment. International Journal of Remote Sensing, 16(7), 1341-1363.

Pu, R., Ge, S., Kelly, N. M., \& Gong, P. (2003). Spectral absorption features as indicators of water status in coast live oak (Quercus agrifolia) leaves. International Journal Remote Sensing, 24, 1799-1810.

Rees, W. G., Tutubalina, O. V., \& Golubeva, E. I. (2004). Reflectance spectra of subarctic lichens between 400 and $2400 \mathrm{~nm}$. Remote Sensing of Environment, 90, 281-292.

Rees, W. G., Williams, M., \& Vitebsky, P. (2003). Mapping land cover change in a reindeer herding area of the Russian Arctic using Landsat TM and ETM+ imagery and indigenous knowledge. Remote Sensing of Environment, 85, 441-452.

Richards, J. A., \& Jia, X. (1999). Remote sensing digital image analysis - An introduction (pp. 363)., 3rd ed. Berlin Springer.

Riedel, S. M., Epstein, H. E., \& Walker, D. A. (2005). Biotic controls over spectral reflectance of arctic tundra vegetation. International Journal of Remote Sensing, 26, 2391 - 2405.

Rock, B. N., Hoshizaki, T., \& Miller, J. R. (1988). Comparison of In Situ and airborne spectral measurements of the Blue Shift associated with forest decline. Remote Sensing of Environment, 24, 109-127.

Sachs, T., Wille, C., Boike, J., \& Kutzbach, L. (2008). Environmental controls on ecosystemscale $\mathrm{CH} 4$ emission from polygonal tundra in the Lena River Delta, Siberia. Journal of Geophysical Research, 113, G00A03. doi:10.1029/2007JG000505

Sazonova, T. S., Romanovsky, V. E., Walsh, J. E., \& Sergueev, D. O. (2004). Permafrost dynamics in 20th and 21st centuries along the East-Siberian Transect. Journal of Geophysical Research, 109, D01108. doi:10.1029/2003JD003680

Schirrmeister, L., Kunitsky, V.V., Grosse, G., Schwamborn, G., Andreev, A. A., Meyer, H., et al. (2003). Late Quaternary history of the accumulation plain north of the Chekanovsky Ridge (Lena Delta, Russia): A multidisciplinary approach. Polar Geography, 27 $277-319$.

Schmidt, K. S., \& Skidmore, A. K. (2003). Spectral discrimination of vegetation types in a coastal wetland. Remote Sensing of Environment, 85, 92-108.

Schneider, J., Grosse, G., \& Wagner, D. (2009). Land cover classification of tundra environments in the Arctic Lena Delta based on Landsat 7 ETM+ data and its application for upscaling of methane emission. Remote Sensing of Environment, 113, 380-391.

Schwamborn, G., Andreev, A. A Rachold, V. Hubberten, H. -W Grigoriev, M. N. Tumskoy, V., et al. (2000). Evolution of Lake Nikolay, Arga Island, Western Lena River Delta, during Late Pleistocene and Holocene time. Polarforschung, 70 $69-82$.

Schwamborn, G., Rachold, V., \& Grigoriev, M. N. (2002). Late Quaternary sedimentation history of the Lena Delta. Quaternary International, 89, 119-134.

Seelig, H. -D., Hoehn, A., Stodieck, L. S., Klaus, D. M., Adams, W. W., III, \& Emery, W. J. (2008). The assessment of leaf water content using leaf reflectance ratios in the visible, near-, and short-wave-infrared. International Journal of Remote Sensing, 29 (13), $3701-3713$.

Soil Survey Staff (2003). Keys to soil taxonomy (pp. 332)., 9th ed. United States Department of Agriculture, Natural Resources Conservation Service.

Stow, D. A., Burns, B. H., \& Hope, A. S. (1993). Spectral, spatial and temporal characteristics of Arctic tundra reflectance. International Journal Remote Sensing $14,2445-2462$

Stow, D. A., Hope, A., McGuire, D., Verbyla, D., Gamon, J., Huemmrich, F., et al. (2004). Remote sensing of vegetation and land-cover in arctic tundra ecosystems. Remote Sensing of Environment, 89, 281-308.

Tou, J. T., \& Gonzalez, R. C. (1974). Pattern recognition principles. Reading, Massachusetts Addison-Wesley Publishing Company.

Ulrich, M., \& Grosse, G. (2007). Characteristics and spectral properties of periglacial landforms. In L. Schirrmeister, D. Wagner, M. N. Grigoriev \& D.Yu. Bolshiyanov (Eds.), Russian-German Cooperation SYSTEM LAPTEV SEA - The Expedition Lena2005. Reports on Polar and Marine Research, Vol. 550 Appendix 4-1, 4-3, hdl:10013/ epic.26642.d001.

van Til, M., Bijmer, A., \& de Lange, R. (2004). Seasonal variability in spectral reflectance of coastal dune vegetation. EARSel eProceedings, 3, 154-165.

van der Meer, F. (2004). Analysis of spectral absorption features in hyperspectral imagery. International Journal of Applied Earth Observation and Geoinformation, 5, 55-68.

Vierling, L. A., Deering, D. W., \& Eck, T. F. (1997). Differences in arctic tundra vegetation type and phenology as seen using bidirectional radiometry in the early growing season. Remote Sensing of Environment, 60, 71-82.

Wagner, D., Kobabe, S., Pfeiffer, E. M., \& Hubberten, H. W. (2003). Microbial controls on methane fluxes from polygonal tundra of the Lena Delta, Siberia. Permafrost and Periglacial Processes, 14, 173-185.

Wagner, D., Gattinger, A., Embacher, A., Pfeiffer, E. -M., Schloter, M., \& Lipski, A. (2007) Methanogenic activity and biomass in Holocene permafrost deposits of the Lena Delta, Siberian Arctic and its implication for the global methane budget. Global Change Biology, 13, 1089-1099. doi:10.1111/j.1365-2486.2007.01331.x

Walter, K. M., Edwards, M. E., Grosse, G., Zimov, S. A., \& Chapin, F. S., III (2007). Thermokarst Lakes as a source of atmospheric $\mathrm{CH} 4$ during the last deglaciation. Science, 318, 633-636.

Walter, K. M., Zimov, S. A., Chanton, J. P., Verbyla, D., \& Chapin, F. S., III (2006). Methane bubbling from Siberian Thaw Lakes as a positive feedback to climate warming. Nature, 443, 71-75.

Weidong, L., Baret, F., Xingfa, G., Qingxi, T., Lanfen, Z., \& Bing, Z. (2002). Relating soil moisture to reflectance. Remote Sensing of Environment, 81, 238-246.

Wetterich, S., Kuzmina, S., Andreev, A. A., Kienast, F., Meyer, H., Schirrmeister, L., et al. (2008). Palaeoenvironmental dynamics inferred from late Quaternary permafrost deposits on Kurungnakh Island (Lena Delta, Northeast Siberia, Russia). Quaternary Science Reviews, 27, 1523-1540. 
WWIS (2006). World weather information service. http:// www.worldweather.org/107/ c01040.html

Zhang, T., Barry, R. G., Knowles, K., Heginbottom, J. A., \& Brown, J. (1999). Statistics and characteristics of permafrost and ground ice distribution in the Northern Hemisphere. Polar Geography, 23, 132-154.
Zhang, T., Roger, G. B., \& Armstrong, R. L. (2004). Application of satellite remote sensing techniques to frozen ground studies. Polar Geography, 28, 163-196.

Zimov, S. A., Schuur, E. A. G., \& Chapin, F. S., III (2006). Permafrost and the global carbon budget. Science, 312, 1612-1613. 